\title{
Technologie-indicatoren: bevolking, arbeid en scholing : rapportage 1991
}

Citation for published version (APA):

van Dam, J. W., Lodder, B. J. H., \& Ramaekers, G. W. M. (1991). Technologie-indicatoren: bevolking, arbeid en scholing : rapportage 1991. Researchcentrum voor Onderwijs en Arbeidsmarkt, Faculteit der Economische Wetenschappen. ROA Reports No. 9 https://doi.org/10.26481/umarep.1991009

Document status and date:

Published: 01/01/1991

DOI:

10.26481/umarep.1991009

Document Version:

Publisher's PDF, also known as Version of record

\section{Please check the document version of this publication:}

- A submitted manuscript is the version of the article upon submission and before peer-review. There can be important differences between the submitted version and the official published version of record.

People interested in the research are advised to contact the author for the final version of the publication, or visit the DOI to the publisher's website.

- The final author version and the galley proof are versions of the publication after peer review.

- The final published version features the final layout of the paper including the volume, issue and page numbers.

Link to publication

\footnotetext{
General rights rights.

- You may freely distribute the URL identifying the publication in the public portal. please follow below link for the End User Agreement:

www.umlib.nl/taverne-license

Take down policy

If you believe that this document breaches copyright please contact us at:

repository@maastrichtuniversity.nl

providing details and we will investigate your claim.
}

Copyright and moral rights for the publications made accessible in the public portal are retained by the authors and/or other copyright owners and it is a condition of accessing publications that users recognise and abide by the legal requirements associated with these

- Users may download and print one copy of any publication from the public portal for the purpose of private study or research.

- You may not further distribute the material or use it for any profit-making activity or commercial gain

If the publication is distributed under the terms of Article $25 \mathrm{fa}$ of the Dutch Copyright Act, indicated by the "Taverne" license above, 
TECHNOLOGIE-INDICATOREN: BEVOLKING, ARBEID EN SCHOLING -Rapportage 1991-

ROA-R-1991/9

J.W. van Dam

B.J.H. Lodder

G.W.M. Ramaekers

RESEARCHCENTRUM VOOR ONDERWIJS EN ARBEIDSMARKT

Faculteit der Economische Wetenschappen

Rijksuniversiteit Limburg

Maastricht, december 1991 
TECHNOLOGIE-INDICATOREN: BEVOLKING, ARBEID EN SCHOLING

-Rapportage 1991-

ROA-R-1991/9

J.W. van Dam

B.J.H. Lodder

G.W.M. Ramaekers

RESEARCHCENTRUM VOOR ONDERWIJS EN ARBEIDSMARKT

Faculteit der Economische Wetenschappen

Rijksuniversiteit Limburg

Maastricht, december 1991 
Dam, J.W. van

Technologie-indicatoren: bevolking, arbeid en scholing: rapportage 1991/ J.W. van Dam, B.J.H. Lodder, G.W.M. Ramaekers. - Maastricht: Researchcentrum voor Onderwijs en Arbeidsmarkt, Faculteit der Economische Wetenschappen, Rijksuniversiteit Limburg. - III., Fig., tab. (Rapport/Researchcentrum voor Onderwijs en Arbeidsmarkt, ISSN 0922-8098; 1991/9)

Met lit. opg.

ISBN 90-5321-069-5 geb.

Trefw.: onderwijs en arbeidsmarkt. 


\section{INHOUDSOPGAVE}

TABELLEN EN FIGUREN

VERANTWOORDING

1. INLEIDING 1

2. ACTUALISERING VAN KERNINDICATOREN

2.1. Inleiding 3

2.2. Initieel onderwijs 4

2.2.1. Duaal onderwijs 4

2.2.2. Aandeel beroepsonderwijs in het totale reguliere onderwijs 5

$\begin{array}{ll}\text { 2.3. Scholingsnoodzaak } & 7\end{array}$

2.3.1. Arbeidsmarktsituatie voor technisch geschoolden: spanningsindicatoren 7

2.3.2. Leeftijdsopbouw (beroeps)bevolking en afhankelijkheidsgraad 8

2.4. Scholingsinspanningen 14

2.4.1. Aandeel van de potentiële beroepsbevolking dat scholing volgt 14

$\begin{array}{ll}\text { 2.4.2. Aandeel van werknemers met een leerovereenkomst per bedrijfssector } & 15\end{array}$

3. RESPONS VANUIT HET RELATIENETWERK EN AANVULLENDE DATABRONNEN 18

3.1. Mailing en respons vanuit het relatienetwerk 18

3.2. Europese instituten en integratie van dataverzameling 18

3.3. Incidentele onderzoeken 20

3.3.1. Talenkennis en talenbehoefte 20

3.3.2. Schoolgang en werkloosheid bij jongeren in Europa 24

3.3.3. IRDAC-rapportage over kwalificatietekorten in Europa 27

3.3.4. Baanmobiliteit 29

4. ONDERWIJS EN SCHOLING IN ZWEDEN

4.1. Inleiding 31

4.2. Economie en arbeidsmarkt 31

4.3. Onderwijssysteem 33

4.4. Scholing 34

4.5. Betrokken partijen bij arbeidsmarkt- en scholingsbeleid 36

4.6. Conclusies 37 
5. VROUWEN IN TECHNISCHE OPLEIDINGEN EN BEROEPEN 38

5.1. Inleiding 38

5.2. Exacte vakken op de middelbare school 38

5.3. Keuze voor een technische vervolgopleiding 42

5.4. Aandeel van vrouwen in schoolverlaters van technische opleidingen 45

5.5. Aandeel van vrouwen in technische beroepen 46

5.6. Conclusies 49

6. CONCLUSIES

$\begin{array}{ll}\text { LITERATUUR } & 53\end{array}$

BIJLAGE I: INDELING BEDRIJFSSECTOREN

BIJLAGE II: TOEGEZONDEN PUBLICATIES PER LAND

BIJLAGE III: TOELICHTING ONDERWIJSTABELLEN 


\section{TABELLEN EN FIGUREN}

\section{Kernindicatoren}

Tabel 1 : Percentage leerlingen duaal stelsel t.o.v. totale bevolking van 15-24 jaar

Tabel 2 : Indicator aandeel beroepsonderwijs ( $2 \mathrm{e}$ en $3 \mathrm{e}$ niveau)

Tabel 3 : Werkloosheidspercentages schoolverlaters (cijfers mei)

Tabel 4 : Leeftijdsopbouw van de totale bevolking (\%)

Tabel 5 : Leeftijdsopbouw van de actieve bevolking (\%)

Tabel 6 : Ontwikkeling van de afhankelijkheidsgraad in 7 industrielanden

Figuur 1 : Afhankelijkheidsgraad in de twaalf lidstaten van de Europese Gemeenschap: 1985, 2025

Tabel 7 : Scholingsparticipatie van de potentiële beroepsbevolking 15-49 jaar (in ruime zin)

Tabel 8 : Scholingsparticipatie van de potentiële beroepsbevolking 15-49 jaar (in enge zin)

Tabel 9 : Aandeel van primaire leerovereenkomsten in het arbeidsvolume per bedrijfssector (\%)

Tabel 10 : Aandeel van voortgezette leerovereenkomsten in het arbeidsvolume per bedrijfssector $(\%)$

Talenkennis en talenbehoefte

Tabel 11 : Nederlandse export naar taalgebied (\%)

Tabel 12 : Behoefte aan kennis van vreemde talen in het Nederlandse bedrijfsleven (\%)

Tabel 13a : Percentages zakenlieden die zich enigermate in het Engels, Frans en Duits kunnen uiten

Tabel 13b : De talen Engels, Frans of Duits waarin zakenlieden zich enigermate kunnen uiten (\%)

Tabel 14 : Problemen bij het gebruik van Engels, Frans en Duits in het Nederlandse bedrijfsleven (\%)

Tabel 15 : Het aantal op school geleerde en het aantal correct gesproken talen, met uitzondering van de moedertaal

Schoolgang en werkloosheid bij jongeren in Europa

Figuur 2 : Schoolparticipatie voor verschillende leeftijdscategorieën in de EG (\%)

Tabel 16 : Werkloosheidspercentages in de leeftijdsklasse 14-24 jaar in de EG, 1985

Figuur 3 : Werkloosheidspercentages in de leeftijdsklasse 14-24 jaar in de EG, 1985

IRDAC-rapportage over kwalificatietekorten

Tabel 17 : Indicatoren voor de relatieve betekenis van ingenieursdisciplines en exacte wetenschappen in het universitair onderwijs en van ingenieurs in de beroepsbevolking

Figuur 4 : Voorspelde vraag naar opleidingscategorieën in de jaren '90 
Baanmobiliteit

Tabel 18 : Omvang baan-baanmobiliteit bij een krappe arbeidsmarkt (\% van het aantal werknemers)

Onderwijs en scholing in Zweden

Tabel 19 : Groei van het reële Bruto Nationaal Produkt (\% mutatie ten opzicht van het vorige jaar)

Tabel 20 : Ontwikkeling van het werkloosheidspercentage, 1987-1992

Tabel 21 : Uitgaven aan onderwijs per hoofd van de bevolking tussen 5 en 24 jaar in Zweden (vergeleken met het EG-gemiddelde $=100$ )

Tabel 22 : Indicatoren voor (beroepsgerichte) volwasseneneducatie en scholing door bedrijven

Figuur 5 : Invloed van actoren op het onderwijs in Zweden

Vrouwen in technische opleidingen en beroepen

Tabel 23 : Aantal exacte vakken in het eindexamenpakket op de middelbare school naar geslacht

Tabel 24 : Soort exacte vakken in het eindexamenpakket op de middelbare school naar geslacht

Tabel 25 : Keuze voor het LTO/LNO als percentage van de keuze voor het LBO

Tabel 26 : Keuze voor het MTO/MNO als percentage van de keuze voor het MBO

Tabel 27 : Keuze voor het HTNO als percentage van de keuze voor het HBO

Tabel 28 : Aandeel van vrouwen in de eerstejaars studenten van technische en natuurwetenschappelijke studierichtingen in het WO (\%)

Tabel 29 : Aandeel van vrouwen in technische studierichtingen op wetenschappelijk niveau (\%)

Tabel 30 : Aandeel van vrouwelijke schoolverlaters met een technische opleiding (\%)

Tabel 31 : Aandeel van vrouwen in technische beroepen; gemiddelde percentage en ontwikkelingstrend

Tabel 32 : Aandeel van vrouwen in technische beroepsklassen; gemiddelde percentage en ontwikkelingstrend

Tabel 33 : Aandeel van vrouwen in beroepssector 'professional, technical and related workers' (ISCO 0/1) 


\section{VERANTWOORDING}

Dit onderzoek werd uitgevoerd in opdracht van het Nederlandse Ministerie van Economische Zaken, directie Algemeen Technologiebeleid. Het onderzoek werd uitgevoerd door drs. J.W. van Dam, drs. B.J.H. Lodder en drs. G.W.M. Ramaekers (projectleider) met assistentie van P. Ghijssen.

Het was het derde onderzoek dat door het ROA is verricht in het kader van een databank voor het technologiebeleid 'METING'. Het eerste onderzoek werd in 1989 uitgevoerd door dr. A. de Grip en mevr. drs. W.J. Nusselder. Van dit project is verslag gedaan in het ROA-rapport 'Technologie-indicatoren met betrekking tot scholing en arbeid' (ROA-R-1989/4), welke tevens in het Engels is verschenen (ROA-R-1989/4E). Het tweede onderzoek, uitgevoerd door drs. J.W. van Dam en dr. A. de Grip, vond plaats in 1990. Hiervan is verslag gedaan in het ROA-rapport 'Technologie-indicatoren: bevolking, arbeid en scholing. Rapportage 1990 (ROA-R-1990/5), dat tevens in een Engelse vertaling is verschenen (ROA-R-1990/5E).

Het thans voorliggende rapport is daarop een vervolg. De studie bestaat uit twee delen. In het eerste deel zijn vijf van de zes kernindicatoren, die reeds in 1989 werden ontwikkeld, voorzien van actuele cijfers, gevolgd door een korte interpretatie (zie hoofdstuk 2). In hoofdstuk 3 wordt, evenals vorig jaar, een aantal cijfers gepresenteerd met betrekking tot bevolking, arbeid en scholing die van belang kunnen zijn voor het technologiebeleid. In het tweede deel worden twee deelstudies gepresenteerd. De eerste heeft betrekking op onderwijs en scholing in Zweden (hoofdstuk 4). In de tweede deelstudie wordt ingegaan op het aandeel van vrouwen in technische opleidingen en beroepen (hoofdstuk 5). Het rapport wordt afgesloten met een korte evaluatie en enkele aanbevelingen. 


\section{INLEIDING}

In het rapport 'METING 2, Indicatoren voor de technologische positiebepaling van Nederland' (Ministerie van Economische Zaken, 1990) worden de opzet en doelstellingen van de databank voor technologie-indicatoren 'METING' weergegeven. Eén van de vijf categorieën van indicatoren waaruit deze databank is opgebouwd heeft betrekking op het technologisch potentieel van de beroepsbevolking als indicatie voor de voedingsbodem voor technologische ontwikkelingen. Hiervoor zijn vorig jaar een zestal internationaal vergelijkbare kernindicatoren met betrekking tot bevolking, arbeid en scholing geselecteerd (zie Van Dam en De Grip, 1990): Relatieve deelname aan het duale onderwijs, het aandeel van het beroepsonderwijs in het totale reguliere onderwijs, het aandeel van technisch geschoolden in het totaal aantal schoolverlaters en in de beroepsbevolking, de arbeidsmarktsituatie voor technisch geschoolden, de leeftijdsopbouw van de (economisch actieve) bevolking en het aandeel van de beroepsbevolking dat scholing volgt. Het onderzoek bestaat dit jaar uit twee delen. Het eerste deel betreft een actualisering van de genoemde kernindicatoren voor de maatschappelijke voedingsbodem voor technologische vernieuwingen. Deze zijn voornamelijk gebaseerd op internationale statistische databronnen van ILO, UNESCO, Eurostat en OECD. Tevens is opnieuw het inmiddels opgebouwde netwerk van buitenlandse statistische bureaus benaderd met als doel te komen tot een aanvulling van de genoemde kernindicatoren en eventueel nieuwe indicatoren. Dit netwerk omvat circa 60 statistische bureaus, onderzoekinstituten en/of onderzoekers uit Nederland, West-Duitsland, Frankrijk, het Verenigd Koninkrijk, Zweden, de Verenigde Staten en Japan. Onder WestDuitsland wordt in dit rapport verstaan, de voormalige Bondsrepubliek Duitsland van vóór de hereniging in 1990.

Tussen technologische ontwikkelingen enerzijds en onderwijs en arbeid anderzijds is er sprake van een wederkerige relatie. In de eerste plaats is de scholing van de beroepsbevolking een belangrijke determinant van de Research \& Development capaciteiten van een land. De scholingsgraad van de beroepsbevolking beïnvloedt op deze wijze het innovatievermogen van de samenleving. Echter, de optredende technologische ontwikkelingen hebben op hun beurt gevolgen voor onder meer de omvang en samenstelling van de werkgelegenheid, voor de inhoud van functies, voor de daaraan gekoppelde scholingseisen en voor de hieruit resulterende aard en niveau van de vereiste scholing. De scholingsgraad van de beroepsbevolking is in dit verband een belangrijke determinant van het diffusiepotentiee/ van technologische ontwikkelingen.

In hoofdstuk twee worden de geactualiseerde kernindicatoren gepresenteerd. Daarbij is grotendeels dezelfde indeling gehanteerd als vorig jaar. In hoofdstuk 3 komen de resultaten van het inventariserende onderzoek naar aanvullende data met betrekking tot bevolking, arbeid en 
$-2-$

scholing van enkele geselecteerde geïndustrialiseerde landen aan de orde. Het tweede deel van het rapport is toegespitst op een tweetal specifieke onderwerpen. In de eerste plaats op de aansluiting onderwijs-arbeidsmarkt in Zweden, waarbij met name wordt gekeken naar het beroepsonderwijs, duale trajecten en bedrijfsopleidingen. Dit komt in hoofdstuk 4 aan bod. Vervolgens wordt in hoofdstuk 5 ingegaan op het aandeel van vrouwen in technische opleidingen en beroepen. Het rapport wordt afgesloten met een aantal conclusies en aanbevelingen. 


\section{ACTUALISERING VAN KERNINDICATOREN}

\subsection{Inleiding}

Dit jaar is de aandacht gericht op het actualiseren van een vijftal van de vorig jaar geselecteerde 'kernindicatoren' voor de maatschappelijke voedingsbodem voor technologische vernieuwingen: relatieve deelname aan het duaal onderwijs, het aandeel van het beroepsonderwijs in het totale reguliere onderwijs, de arbeidsmarktsituatie voor technisch geschoolden, de leeftijdsopbouw van de (economisch actieve) bevolking en het aandeel van de beroepsbevolking dat scholing volgt. In de rapportage 1990 was nog een zesde kernindicator opgenomen, namelijk het aandeel van technisch geschoolden in het totaal aantal schoolverlaters en in de beroepsbevolking. De prognoses voor deze indicator liepen tot het jaar 2000. Deze indicator kon dit jaar niet tijdig worden geactualiseerd aangezien de SKILL-prognose van het Ministerie van Onderwijs en Wetenschappen, die aan de actualisering van deze indicator ten grondslag ligt, met ingang van dit jaar is vervangen door de 'referentieraming' van het Ministerie van Onderwijs en Wetenschappen. Inmiddels is de nieuwe referentieraming '91 gereed. Het tijdstip waarop de uitkomsten van de raming beschikbaar kwamen, maakte het voor het ROA echter onmogelijk om op verantwoorde wijze van de nieuwe prognoses gebruik te maken. Vandaar dat voor de meest recent geactualiseerde versie van deze indicator wordt verwezen naar de rapportage van het vorige jaar.

Het onderzoek met betrekking tot de indicatoren bestaat ook dit jaar uit twee delen: enerzijds betreft het een actualisering van de genoemde kernindicatoren op basis van internationale statistische databronnen van ILO, UNESCO, Eurostat en OECD. De resultaten worden in dit hoofdstuk gepresenteerd. Het tweede deel van deze studie bevat de resultaten van een inventariserend onderzoek onder buitenlandse statistische bureaus e.d. naar de beschikbaarheid van data met betrekking tot bevolking, arbeid en scholing, met als doel te komen tot een aanvulling van de genoemde kernindicatoren en de ontwikkeling van nieuwe indicatoren. Dit verkennend onderzoek was gericht op enkele geselecteerde geïndustrialiseerde landen: Nederland, West-Duitsland, Frankrijk, het Verenigd Koninkrijk, Zweden, de Verenigde Staten en Japan. Het inmiddels opgebouwde netwerk van circa 60 statistische bureaus, onderzoeksinstituten en/of onderzoekers uit deze landen is aangeschreven met het verzoek om data of onderzoeksverslagen aan te leveren. De resultaten hiervan komen in hoofdstuk 3 aan bod.

De hier gepresenteerde indicatoren moeten aan een aantal criteria voldoen. Allereerst moeten de indicatoren bruikbaar zijn voor de verschillende aspecten van het Algemene Technologie Beleid. Tevens moeten de indicatoren realiseerbaar zijn. Ten derde wordt gestreefd naar een enigszins 
$-4-$

evenwichtige verdeling tussen input en output indicatoren. Op de vierde plaats moet een aantal indicatoren inzicht geven in de maatschappelijke aspecten van technologische ontwikkelingen. Ten vijfde moet het mogelijk zijn de indicatoren ook voor andere landen samen te stellen, zodat internationale vergelijkingen mogelijk zijn. Tenslotte moeten de bronnen die als basis dienen om de indicatoren te berekenen enige continuïteit kunnen garanderen. Evenals vorig jaar hebben ook dit jaar met name de laatste twee criteria een grote rol gespeeld bij het samenstellen van dit rapport.

Bij de presentatie in dit hoofdstuk van de geactualiseerde kernindicatoren is grotendeels dezelfde indeling gehanteerd als vorig jaar. In paragraaf 2.2. wordt ingegaan op twee indicatoren voor de bijdrage van het initiële onderwijs aan de toekomstige voedingsbodem voor technologische ontwikkelingen, namelijk de relatieve deelname aan het duale onderwijs en het aandeel van het beroepsonderwijs in het totale reguliere onderwijs. In paragraaf 2.3. worden twee indicatoren gepresenteerd die een maatstaf vormen voor de noodzaak tot scholing ter bestrijding van actuele of mogelijke toekomstige knelpunten die een verdere diffusie van technologische ontwikkelingen kunnen belemmeren. Deze indicatoren zijn: de arbeidsmarktsituatie voor technisch geschoolden en de leeftijdsopbouw van de (beroeps)bevolking. De laatstgenoemde indicator is dit jaar uitgebreid met de daarmee verbonden afhankelijkheidsgraad. Tenslotte volgen in paragraaf 2.4. een tweetal indicatoren die een maatstaf vormen voor de huidige scholingsinspanningen, waarmee op knelpunten wordt ingespeeld. Deze indicatoren betreffen het aandeel van de beroepsbevolking dat scholing volgt en het aandeel van leerovereenkomsten per bedrijfssector. De laatstgenoemde indicator is dit jaar voor het eerst opgenomen.

\subsection{Initieel onderwijs}

\subsubsection{Duaal onderwijs}

Duaal onderwijs is de verzamelnaam voor onderwijsvormen die bestaan uit een combinatie van leren en werken en daardoor een voorbereiding geven voor aankomend vakmanschap. In Nederland wordt duaal onderwijs voornamelijk gegeven in de vorm van het leerlingwezen. De participatiegraad van jongeren in het duale onderwijs kan, zoals in De Grip en Nusselder (1989) reeds werd aangegeven, gezien worden als een indicatie voor de wetenschappelijke en technologische voedingsbodem voor met name de diffusie van technologische ontwikkelingen.

Het aantal leerlingen in het duale onderwijs kan worden berekend op basis van de resultaten van de Labour Force Survey (1983-1989) van de Europese Gemeenschap. In deze survey wordt aan 
personen tussen de 15 en 50 jaar gevraagd naar het soort scholing' dat wordt gevolgd vier weken voorafgaand aan de survey en het doel van de scholing. Evenals vorig jaar is het aantal personen dat duaal onderwijs volgt, gerelateerd aan ILO-gegevens over het totale aantal personen in het leeftijdscohort van 15-24 jaar. Dit maakt een vergelijking tussen de verschillende landen mogelijk.

De gegevens van tabel 1 zijn mogelijk enigszins vertekend door verschuivingen in de nonrespons van de survey en dienen derhalve met enige voorzichtigheid te worden geïnterpreteerd. Desalniettemin is goed te zien dat het duale onderwijs in Denemarken en West-Duitsland ondanks de lichte daling in 1989, een veel belangrijker plaats blijft innemen dan in de overige landen. Nederland bevindt zich duidelijk in de lagere regionen. De in 1988 ingezette daling van het percentage voor Nederland zet zich in 1989 voort. In Italië en België is daarentegen sprake van een lichte stijging in 1989. De in de tweede helft van de jaren tachtig ingezette toename in Frankrijk en het Verenigd Koninkrijk zet zich in 1989 gestaag voort. Bij Luxemburg zien we een tegenstelde ontwikkeling, waarbij de na 1985 ingezette daling zich ook in 1989 gestaag voortzet. lerland en Griekenland geven een stabiel laag beeld te zien. Vooralsnog kan deze indicator alleen voor de EG-landen worden weergegeven.

Tabel 1. Percentage leerlingen duaal stelsel t.o.v. totale bevolking van 15-24 jaar

\begin{tabular}{|c|c|c|c|c|c|c|c|}
\hline & $\begin{array}{c}1983 \\
\%\end{array}$ & $\begin{array}{c}1984 \\
\% \\
\end{array}$ & $\begin{array}{c}1985 \\
\% \\
\end{array}$ & $\begin{array}{c}1986 \\
\% \\
\end{array}$ & $\begin{array}{c}1987 \\
\% \\
\end{array}$ & $\begin{array}{c}1988 \\
\%\end{array}$ & $\begin{array}{c}1989 \\
\% \\
\end{array}$ \\
\hline Nederland & 2.5 & 2.4 & 2.3 & 2.3 & 2.3 & 1.9 & 1.7 \\
\hline Frankrijk & 2.6 & 2.6 & 2.5 & 2.4 & 2.6 & 2.8 & 2.9 \\
\hline West-Duitsland & 10.0 & 13.5 & 15.5 & 17.7 & 17.4 & 17.7 & 17.5 \\
\hline Verenigd Koninkrijk & 7.6 & 5.0 & 5.6 & 4.8 & 4.9 & 5.3 & 5.7 \\
\hline Italië & 0.5 & 0.6 & 0.5 & 0.6 & 0.6 & 0.6 & 0.8 \\
\hline België & 2.3 & 1.9 & 1.8 & 1.9 & 1.6 & 1.3 & 1.5 \\
\hline Luxemburg & 5.8 & 6.3 & 7.0 & 6.1 & 5.7 & 5.1 & 4.8 \\
\hline lerland & 2.8 & 2.2 & 2.5 & 2.0 & 1.9 & -- & 2.0 \\
\hline Denemarken & 7.4 & 18.8 & 22.1 & 22.7 & 23.7 & 23.8 & 20.4 \\
\hline Griekenland & 0.3 & 0.3 & 0.4 & 0.5 & 0.3 & 0.3 & 0.3 \\
\hline
\end{tabular}

\subsubsection{Aandeel beroepsonderwijs in het totale reguliere onderwijs}

De in deze sub-paragraaf gepresenteerde indicator geeft het aandeel van de

1. In deze survey wordt ten aanzien van het duale onderwijs een onderscheid gemaakt tussen "apprenticeship" (leercontract) en andere vormen van duaal onderwijs. 
leerlingen/studenten in het beroepsonderwijs (tweede en derde niveau ${ }^{2}$ ) ten opzichte van het totaal aantal leerlingen/studenten in het tweede en derde niveau weer. Op basis van het Statistical Yearbook van de Unesco (1983-1988) is het mogelijk een uitsplitsing te maken naar beroepsonderwijs en algemeen onderwijs. Bij het berekenen van de indicator wordt het onderwijs op het derde niveau (Hoger Onderwijs) geheel tot het beroepsonderwijs gerekend.

De bovengenoemde ratio geeft met name een indicatie van de mate waarin mensen in hun latere werkkring open staan voor technologische ontwikkelingen. Hieraan ligt de veronderstelling ten grondslag dat mensen die een brede initiële beroepsopleiding hebben gevolgd doorgaans beter kunnen inspelen op vernieuwingen, dan arbeidskrachten die in de beroepspraktijk zijn geschoold. Doorgaans is met name de theoretische kennis bij de laatstgenoemde scholing minder breed. Deze indicator kan dan ook worden gezien als een indicator voor de wetenschappelijke en technologische voedingsbodem voor de diffusie van technologische veranderingen. Mogelijkerwijs kan een hoger aandeel van het beroepsonderwijs ook gezien worden als een vergroting van het innovatiepotentieel van de samenleving.

Tabel 2 laat zien dat in Nederland, Zweden en West-Duitsland het aandeel van de leerlingen in het beroepsonderwijs het hoogste is. In het Verenigd Koninkrijk en Japan is dit aandeel beduidend lager. Oostenrijk en Frankrijk nemen een tussenpositie in.

In Nederland en Zweden blijft de bovengenoemde indicator stabiel hoog. In de meeste landen, met name West-Duitsland, het Verenigd Koninkrijk en Oostenrijk, vertoont de indicator een stijgende tendens. Aan de gestage daling in Japan lijkt in 1988 een einde te zijn gekomen.

Tabel 2. Indicator aandeel beroepsonderwijs (2e en $3 e$ niveau)

\begin{tabular}{|c|c|c|c|c|c|c|c|c|c|c|}
\hline & $\begin{array}{c}1975 \\
\% \\
\end{array}$ & $\begin{array}{c}1980 \\
\% \\
\end{array}$ & $\begin{array}{c}1981 \\
\% \\
\end{array}$ & $\begin{array}{c}1982 \\
\% \\
\end{array}$ & $\begin{array}{c}1983 \\
\% \\
\end{array}$ & $\begin{array}{c}1984 \\
\% \\
\end{array}$ & $\begin{array}{c}1985 \\
\% \\
\end{array}$ & $\begin{array}{c}1986 \\
\% \\
\end{array}$ & $\begin{array}{c}1987 \\
\% \\
\end{array}$ & $\begin{array}{c}1988 \\
\%\end{array}$ \\
\hline Nederland & 51 & 53 & 53 & 54 & 55 & 55 & 56 & 57 & 57 & -- \\
\hline Frankrijk & 35 & 36 & 36 & 40 & 38 & 39 & 36 & 40 & 38 & 39 \\
\hline West-Duitsland & 32 & 33 & 35 & 37 & 29 & 31 & 32 & 48 & 49 & 50 \\
\hline Verenigd Koninkrijk & 16 & 18 & 19 & 19 & 20 & 23 & 24 & 26 & 27 & -- \\
\hline Zweden & 45 & 45 & 46 & 49 & 51 & 51 & -- & 50 & 50 & 51 \\
\hline Oostenrijk & 25 & 33 & 33 & 35 & 37 & 40 & 41 & 43 & 43 & 44 \\
\hline Verenigde Staten & -- & -- & -- & -- & -- & -- & -- & -- & -- & -- \\
\hline Janan & 34 & 32 & 32 & 30 & 30 & 29 & 28 & 28 & 28 & 29 \\
\hline
\end{tabular}

Bron: UNESCO $(1984,1985,1986,1987,1988,1989)$

Legenda: -- = nog niet aanwezig

2. Het tweede en derde niveau omvat alle onderwijs na het basisonderwijs. 


\subsection{Scholingsnoodzaak}

2.3.1. Arbeidsmarktsituatie voor technisch geschoolden: spanningsindicatoren

Tabel 3. Werkloosheidspercentages schoolverlaters (cijfers mei)

\begin{tabular}{|c|c|c|c|c|c|c|c|}
\hline & & 1986 & 1987 & 1988 & 1989 & 1990 & 1991 \\
\hline -LBO & & 19 & 15 & 15 & 14 & 13 & 8 \\
\hline & LTS/ITO & 13 & 10 & 10 & 10 & 8 & 4 \\
\hline$-\mathrm{MBO}$ & & 9 & 8 & 10 & 10 & 7 & 4 \\
\hline & MTS & 5 & 4 & 4 & 5 & 3 & 2 \\
\hline & werktuigbouwkunde & 4 & 3 & 4 & 4 & 2 & 2 \\
\hline & energietechniek & 2 & 2 & 3 & 3 & 3 & 2 \\
\hline & electronica & 6 & 5 & 6 & 7 & 3 & 2 \\
\hline & procestechniek & 4 & 5 & 8 & 8 & 5 & 2 \\
\hline$-H B O$ & & 12 & 10 & 12 & 11 & 9 & 6 \\
\hline & HTS & 4 & 4 & 5 & 5 & 4 & 2 \\
\hline & elektrotechniek & 3 & 2 & 6 & 8 & 6 & 3 \\
\hline & informatica & 2 & 3 & 3 & 6 & 5 & 3 \\
\hline & werktuigbouwkunde & 2 & 2 & 4 & 4 & 2 & 1 \\
\hline & bedrijfskunde & 2 & 4 & 4 & 3 & 4 & 3 \\
\hline -Wo & & 11 & 10 & 9 & 12 & 7 & 4 \\
\hline & Technische Wetenschappen & 6 & 5 & 5 & 6 & 4 & 3 \\
\hline & elektrotechniek & 3 & 1 & 4 & 5 & 3 & 3 \\
\hline & wiskunde & 3 & 4 & 6 & 6 & 3 & 1 \\
\hline & informatica & - & 3 & 2 & 3 & 4 & 3 \\
\hline & bedrijfskunde & 7 & 2 & 3 & 3 & 7 & 1 \\
\hline \multicolumn{2}{|l|}{ Totaal } & 14 & 11 & 12 & 12 & 11 & 8 \\
\hline
\end{tabular}

Bron: Van Paridon/ROA

Eventuele knelpunten op de arbeidsmarkt voor technisch opgeleiden kunnen worden weergegeven door een door Van Paridon ontwikkelde arbeidsmarktindicator waarin het percentage schoolverlaters van het meest recente cohort, dat nog werkloos is, tot uitdrukking wordt gebracht (zie De Grip en Heijke, 1988). Daarbij wordt gebruik gemaakt van de bij de GAB's geregistreerde werkloosheidscijfers, waarbij een correctie plaatsvindt in verband met de 
"bestandsvervuiling" ${ }^{3}$. De aldus verkregen indicator vormt, zoals gezegd, een maatstaf waarmee knelpunten op bepaalde segmenten van de arbeidsmarkt kunnen worden gesignaleerd, die een belemmering kunnen vormen voor de diffusie van technologische ontwikkelingen.

Tabel 3 geeft een indicatie van de werkloosheidssituatie in de jaren 1986 tot en met 1991. Uit de tabel kan worden geconcludeerd dat er in 1991 sprake is van een verdergaande daling van de werkloosheid. De arbeidsmarktsituatie van met name technisch opgeleiden is dit jaar nog verder verkrapt. Verder kan geconstateerd worden dat de arbeidsmarktpositie van de niettechnische opleidingen na 1989 is verbeterd. Vooral de werkloosheid onder niet-technische universitair geschoolden is na 1989 sterk gedaald. Opvallend is het herstel van de arbeidsmarktsituatie van de universitaire bedrijfskundigen, die dit jaar erg krap is geworden.

Internationaal vergelijkbare gegevens zijn helaas niet voorhanden in publikaties van internationale organisaties of nationale statistische bureaus.

\subsubsection{Leeftijdsopbouw (beroeps)bevolking en afhankelijkheidsgraad}

Twee indicatoren betreffen de leeftijdsopbouw van respectievelijk de totale bevolking en de actieve (beroeps)bevolking ${ }^{4}$. Deze indicatoren vormen maatstaven voor de ontgroening en vergrijzing van respectievelijk de totale bevolking en de actieve (beroeps)bevolking. Er is daarbij op verzoek van het Ministerie van Economische Zaken niet gekozen voor specifieke indicatoren van ontgroening en vergrijzing, maar voor het geven van een overall beeld van de leeftijdsopbouw van de (beroeps)bevolking.

Het aandeel van 'ouderen' in de beroepsbevolking kan daarbij worden gezien als een maatstaf voor de noodzaak van scholing, voorzover de initiële scholing van de beroepsbevolking veroudert als gevolg van technologische ontwikkelingen. Her-, om- of bijscholing is dan vereist, om deze arbeidskrachten weer produktief te kunnen inzetten. Met andere woorden: de indicator vormt een maatstaf voor de "kwetsbaarheid" van de beroepsbevolking voor technologische ontwikkelingen. Daarnaast vormt deze indicator een maatstaf voor de vereiste "intra-generationele

3. In navolging van Van Paridon wordt verondersteld dat de bestandsvervuiling onder schoolverlaters groot is $(60 \%)$, omdat velen ingeschreven blijven staan wanneer men uitzendwerk of ander tijdelijk werk verricht.

4. De economisch actieve bevolking wordt door de ILO gedefinieerd als alle personen die voorzien in het aanbod van arbeid voor de produktie van goederen en diensten. Zowel werkenden als werklozen behoren tot de actieve bevolking (ILO, 1989). Studenten, gepensioneerden en vrouwen die niet aan het arbeidsproces deelnemen vallen daarentegen buiten deze definitie. 
mobiliteit $^{5 n}$, voorzover technologische ontwikkelingen leiden tot verschuivingen in de beroepenstructuur. Het aandeel van de jongeren (15-24 jaar) in de beroepsbevolking vormt een maatstaf voor de ontgroening van de (beroeps)bevolking. Deze indicator geeft in feite de grenzen aan van de mate waarin een samenleving door het verbeteren van de aansluiting van het initiële onderwijs op de beroepspraktijk kan inspelen op de als gevolg van technologische ontwikkelingen gewijzigde opleidingseisen. Naarmate het percentage jongeren geringer is, zal de reikwijdte van het verbeteren van de afstemming van het initiële onderwijs op de ontwikkelingen op de arbeidsmarkt immers geringer zijn.

Tabel 4 geeft een overzicht van de procentuele aandelen van de vier onderscheiden leeftijdsgroepen in de totale bevolking. Uit deze tabel blijkt dat de Zweedse bevolking het sterkst is 'ontgroend'. In de VS is echter het tempo waarin de bevolking 'ontgroent' het hoogste. Daarentegen is in Japan en Oostenrijk het aandeel van de jongste leeftijdscategorie in de jaren tachtig toegenomen.

Met name de bevolking van West-Duitsland kenmerkt zich door een relatief omvangrijke groep $50+$ ers. Echter de toename van deze oudere leeftijdsgroepen in de loop van de jaren ' 80 is het grootst geweest in Japan.

Tabel 5 geeft de procentuele aandelen van de vier bovengenoemde leeftijdsgroepen in de economisch actieve bevolking weer. Uit deze tabel is af te lezen dat de Verenigde Staten, Oostenrijk, West-Duitsland, Nederland en het Verenigd Koninkrijk een relatief jonge actieve bevolking hebben, terwijl daarentegen het aandeel van $65+$ ers in de actieve bevolking van Japan relatief hoog is. Opvallend is ook het relatief hoge aandeel van de 50-65 jarigen in met name Japan en Zweden. In Japan is het aandeel van deze leeftijdsgroep in de loop van de jaren ' 80 zelfs gestegen. In Nederland en Oostenrijk is het aandeel van de 50-65 jarigen in de actieve bevolking daarentegen het laagst, waarbij er bovendien in de jaren ' 80 een aanzienlijke daling van het aandeel van deze leeftijdsgroep heeft plaatsgevonden. Dit laatste geldt in iets mindere mate ook voor de meeste andere landen.

In de rapportage 1990 zijn ook prognoses van het toekomstige aandeel van ouderen in de Nederlandse (potentiële) beroepsbevolking opgenomen. Voor Nederland zijn dergelijke prognoses het vorige jaar berekend voor de leeftijdsstructuur van zowel de totale bevolking als de leeftijdssamenstelling van de potentiële beroepsbevolking (15-65 jaar). Uit de toen berekende prognoses kwamen de verwachte ontgroening en vergrijzing van de totale bevolking en van de

5. De Grip, (1987). 
potentiële beroepsbevolking goed naar voren. $\mathrm{Er}$ is berekend dat het aandeel van de jongeren (15-24 jaar) in de potentiële beroepsbevolking naar verwachting zal dalen van $23.0 \%$ in 1990 naar slechts $17.4 \%$ in het jaar 2005 . Daarna zal het relatieve aandeel van jongeren naar verwachting weer enigszins toenemen. Daarentegen manifesteert zich een duidelijke toename van het aandeel van de ouderen (50-65 jaar) in de potentiële beroepsbevolking: van $21.2 \%$ in 1990 naar $28.0 \%$ in het jaar 2005 . Naar verwachting zet dit vergrijzingsproces zich daarna nog voort tot circa 2030.

De afhankelijkheidsgraad is de som van het percentage kinderen (0-14 jaar) en het percentage bejaarden $(65+)$, die tesamen het niet-produktieve deel van de bevolking vormen. De hoogte van de afhankelijkheidsgraad vormt een indicatie voor de vereiste arbeidsproduktiviteit van het actieve deel van de bevolking en daarmee voor de noodzaak om door middel van technologie hierin te voorzien. Tabel 6 geeft een beeld van de ontwikkeling van de afhankelijksgraad in een zevental industrielanden. De cijfers vanaf 1990 tot 2020 zijn extrapolaties (volgens de middenvariant) op basis van de voorgaande vijfjaars intervallen. De gegevens zijn afkomstig van de World Population Prospects 1990 van de Verenigde Naties.

In tabel 6 komt de volgende 'over all' ontwikkeling naar voren. $\mathrm{Na}$ een toename in de jaren vijftig, waarschijnlijk als gevolg van de 'baby boom' na de tweede wereldoorlog, neemt de afhankelijkheidsgraad in de jaren zestig, zeventig en tachtig af. Vanaf 1990 gaat deze daling over in een stijging die naar verwachting tot in de volgende eeuw blijft aanhouden. De stijging zal vooral groot zijn in Japan en West-Duitsland. Nederland behoort op dit moment, samen met West-Duitsland, de VS en Japan tot de landen met een relatief lage afhankelijksgraad. Bij de relatief lage afhankelijkheidsgraad in Nederland dient te worden bedacht dat de participatiegraad van vrouwen aan het arbeidsproces in Nederland eveneens relatief laag is. Figuur 1 geeft een visuele voorstelling van de verwachte ontwikkeling met betrekking tot de twaalf landen van de EG. De figuur toont duidelijk aan dat in het jaar 2025, vergeleken met 1985, de afhankelijkheidsgraad beduidend zal zijn toegenomen en dat deze toename vooral op het conto van de vergrijzing kan worden geschreven. Overigens geldt dit beeld niet voor lerland en de twee landen van het lberisch schiereiland, die thans een relatief jonge bevolkingsopbouw hebben en waar bijgevolg een daling van de afhankelijkheidsgraad wordt verwacht. 
Iabel 4. Leeftiidsopbouw van de totale bevolking (\%)

\begin{tabular}{|c|c|c|c|c|c|c|c|c|c|c|c|}
\hline & leeftiid & $\begin{array}{c}1980 \\
\% \\
\end{array}$ & $\begin{array}{c}1981 \\
\% \\
\end{array}$ & $\begin{array}{c}1982 \\
\% \\
\end{array}$ & $\begin{array}{c}1983 \\
\% \\
\end{array}$ & $\begin{array}{c}1984 \\
\% \\
\end{array}$ & $\begin{array}{c}1985 \\
\% \\
\end{array}$ & $\begin{array}{c}1986 \\
\% \\
\end{array}$ & $\begin{array}{c}1987 \\
\% \\
\end{array}$ & $\begin{array}{c}1988 \\
\% \\
\end{array}$ & $\begin{array}{c}1989 \\
\% \\
\end{array}$ \\
\hline \multirow[t]{4}{*}{ Nederland } & $15-24$ & 17.3 & 17.4 & 17.4 & 17.3 & 17.3 & -- & 17.2 & 16.9 & -- & -- \\
\hline & $25-49$ & 34.2 & 34.5 & 35.2 & 35.2 & 35.1 & -- & 36.5 & 37.2 & -- & -- \\
\hline & $50-65$ & 14.4 & 14.5 & 14.5 & 14.6 & 14.6 & -- & 14.7 & 14.7 & - & -- \\
\hline & $65+-$ & 11.5 & 11.6 & 11.7 & 11.7 & 11.7 & -- & 12.2 & 12.5 & -- & - \\
\hline \multirow[t]{4}{*}{ Frankrijk } & $15-24$ & 15.9 & 15.8 & 15.7 & 15.6 & 15.6 & 15.6 & 15.5 & 15.1 & 15.9 & -- \\
\hline & $25-49$ & 33.3 & 33.4 & 33.5 & 33.7 & 33.3 & 34.1 & 34.4 & 35.0 & 35.9 & -- \\
\hline & $50-65$ & 15.3 & 15.8 & 16.2 & 16.6 & 16.7 & 16.5 & 16.4 & 16.4 & 15.8 & -- \\
\hline & $65+-$ & 14.5 & 14.2 & 13.9 & 13.7 & 13.4 & 13.7 & 13.9 & 13.8 & 14.9 & -- \\
\hline \multirow[t]{4}{*}{ West-Duitsland } & $15-24$ & 15.6 & 16.1 & 16.3 & 16.7 & 16.7 & 16.5 & 16.3 & 15.7 & 15.0 & -- \\
\hline & $25-49$ & 34.1 & 34.2 & 34.4 & 35.3 & 35.2 & 35.2 & 35.4 & 35.6 & 35.6 & -- \\
\hline & $50-65$ & 16.2 & 16.6 & 17.1 & 17.3 & 18.1 & 18.4 & 18.4 & 18.6 & 18.9 & -- \\
\hline & $65+-$ & 15.9 & 15.6 & 15.4 & 14.2 & 15.0 & 15.2 & 15.4 & 15.7 & 16.0 & -- \\
\hline \multirow[t]{4}{*}{ Verenigd Koninkrijk } & $15-24$ & - & 15.8 & -- & -- & -- & -- & 16.3 & -- & -- & -- \\
\hline & $25-49$ & -- & 31.8 & -- & -- & -- & -- & 33.2 & -- & -- & -- \\
\hline & $50-65$ & -- & 16.8 & -- & -- & -- & -- & 16.2 & -- & -- & -- \\
\hline & $65+-$ & - & 14.8 & -- & -- & -- & -- & 15.3 & -- & -- & -- \\
\hline \multirow[t]{4}{*}{ Zweden } & $15-24$ & 12.0 & -- & 12.3 & 12.5 & 12.6 & 12.6 & 12.6 & 12.7 & -- & -- \\
\hline & $25-49$ & 33.4 & -- & 33.7 & 34.0 & 34.2 & 34.4 & 34.3 & 34.8 & -- & -- \\
\hline & $50-65$ & 17.3 & -- & 17.0 & 16.8 & 16.6 & 16.3 & 16.2 & 15.7 & -- & -- \\
\hline & $65+-$ & 16.6 & -- & 10.0 & 9.9 & 9.9 & 10.0 & -- & - & -- & -- \\
\hline \multirow[t]{4}{*}{ Oostenrijk } & $15-24$ & 14.4 & 16.7 & 16.7 & 16.6 & 17.0 & 16.9 & 16.7 & 16.3 & 15.9 & -- \\
\hline & $25-49$ & 34.0 & 32.3 & 32.6 & 33.3 & 33.5 & 34.0 & 34.6 & 35.3 & 35.9 & -- \\
\hline & $50-65$ & 15.6 & 15.8 & 16.2 & 16.5 & 16.7 & 16.6 & 16.3 & 16.0 & 15.8 & - \\
\hline & $65+-$ & 15.5 & 15.2 & 14.9 & 14.4 & 14.3 & 14.4 & 14.5 & 14.7 & 14.9 & -- \\
\hline \multirow[t]{5}{*}{ Verenigde Staten } & $15-24$ & 16.9 & 17.3 & 19.5 & -- & 17.0 & 16.6 & 16.2 & 15.7 & 15.2 & 13.5 \\
\hline & $25-49$ & 32.4 & 33.2 & 33.9 & -- & 35.1 & 35.8 & 36.4 & 37.0 & 37.4 & 38.1 \\
\hline & $50-65$ & 14.7 & 14.6 & 14.4 & -- & 14.1 & 13.9 & 13.7 & 13.5 & 13.4 & 13.4 \\
\hline & $65+-$ & 11.2 & 11.4 & 11.6 & - & 11.9 & 11.9 & 12.1 & 12.3 & 12.4 & 12.6 \\
\hline & $15-24$ & 13.8 & 13.6 & 13.7 & 13.8 & 14.0 & 14.2 & 14.4 & 14.7 & 15.0 & 15.2 \\
\hline \multirow{3}{*}{ Japan } & $25-49$ & 38.9 & 38.6 & 38.2 & 37.8 & 37.6 & 37.2 & 36.9 & 36.5 & 36.3 & 36.2 \\
\hline & $50-65$ & 14.7 & 15.1 & 15.5 & 16.0 & 16.4 & 16.8 & 17.2 & 17.5 & 17.8 & 18.0 \\
\hline & $65+-$ & 9.1 & 9.3 & 2.5 & 2.7 & 9.9 & 10.2 & 10.5 & 10.8 & 11.2 & 11.5 \\
\hline
\end{tabular}


Iabel 5. Leeftiidsopbouw van de actieve bevolkina (\%)

\begin{tabular}{|c|c|c|c|c|c|c|c|c|c|c|c|}
\hline & leeftiid & $\begin{array}{c}1980 \\
\% \\
\end{array}$ & $\begin{array}{c}1981 \\
\% \\
\end{array}$ & $\begin{array}{c}1982 \\
\% \\
\end{array}$ & $\begin{array}{c}1983 \\
\% \\
\end{array}$ & $\begin{array}{c}1984 \\
\% \\
\end{array}$ & $\begin{array}{c}1985 \\
\% \\
\end{array}$ & $\begin{array}{c}1986 \\
\% \\
\end{array}$ & $\begin{array}{c}1987 \\
\% \\
\end{array}$ & $\begin{array}{c}1988 \\
\% \\
\end{array}$ & $\begin{array}{c}1989 \\
\% \\
\end{array}$ \\
\hline \multirow[t]{4}{*}{ Nederland } & $15-24$ & 21.6 & 22.0 & 21.5 & 21.6 & 21.6 & -- & 20.2 & 22.4 & 22.0 & 21.3 \\
\hline & $25-49$ & 59.7 & 61.0 & 62.1 & 62.2 & 62.2 & -- & 64.6 & 63.1 & 64.5 & 65.3 \\
\hline & $50-65$ & 17.2 & 16.3 & 15.7 & 15.6 & 15.6 & -- & 14.7 & 13.6 & 13.5 & 13.4 \\
\hline & $65+-$ & 0.5 & 0.7 & 0.6 & 0.7 & 0.7 & -- & 0.6 & 1.0 & -- & -- \\
\hline \multirow[t]{4}{*}{ Frankrijk } & $15-24$ & 17.2 & 16.8 & 16.7 & 16.3 & 16.0 & 15.8 & 15.3 & 13.6 & -- & -- \\
\hline & $25-49$ & 60.4 & 61.0 & 61.7 & 62.7 & 63.4 & 64.1 & 65.0 & 66.6 & -- & -- \\
\hline & $50-65$ & 21.0 & 21.0 & 20.7 & 20.1 & 19.6 & 19.2 & 18.9 & 18.9 & -- & -- \\
\hline & $65+-$ & 1.4 & 1.2 & 0.9 & 0.9 & 0.9 & 0.9 & 0.9 & 0.9 & -- & -- \\
\hline \multirow[t]{4}{*}{ West-Duitsland } & $15-24$ & 20.6 & 20.8 & 20.7 & 20.8 & 21.1 & 21.2 & 20.9 & 20.2 & 19.5 & -- \\
\hline & $25-49$ & 58.1 & 57.9 & 58.0 & 58.4 & 58.1 & 58.2 & 58.2 & 58.4 & 58.6 & -- \\
\hline & $50-65$ & 19.6 & 19.8 & 20.0 & 19.6 & 19.6 & 19.5 & 19.9 & 20.3 & 21.0 & -- \\
\hline & $65+-$ & 1.6 & 1.5 & 1.3 & 1.3 & 1.2 & 1.1 & 1.0 & 1.0 & 1.0 & -- \\
\hline \multirow[t]{4}{*}{ Verenigd Koninkrijk } & $15-24$ & -- & 21.0 & -- & -- & -- & -- & 22.9 & -- & -- & -- \\
\hline & $25-49$ & -- & 53.3 & -- & -- & -- & -- & 55.3 & -- & -- & -- \\
\hline & $50-65$ & -- & 23.6 & -- & -- & -- & -- & 20.3 & -- & -- & -- \\
\hline & $65+-$ & -- & 2.0 & -- & -- & -- & -- & 1.5 & -- & -- & -- \\
\hline \multirow[t]{4}{*}{ Zweden } & $15-24$ & 14.5 & -- & 15.7 & 15.5 & 15.5 & 15.7 & 16.2 & 16.0 & -- & 16.3 \\
\hline & $25-49$ & 58.5 & -- & 58.5 & 59.1 & 59.7 & 60.1 & 60.4 & 61.3 & -- & 61.5 \\
\hline & $50-65$ & 25.3 & -- & 24.2 & 23.9 & 23.5 & 22.9 & 23.4 & 22.7 & -- & 22.1 \\
\hline & $65+-$ & 1.7 & -- & 1.6 & 1.5 & 1.3 & 1.3 & -- & -- & -- & -- \\
\hline \multirow[t]{4}{*}{ Oostenrijk } & $15-24$ & 19.7 & 25.4 & 23.3 & 23.5 & 24.6 & 24.1 & 23.9 & 23.7 & 22.7 & -- \\
\hline & $25-49$ & 59.8 & 56.5 & 58.2 & 58.9 & 58.5 & 59.8 & 60.7 & 61.4 & 62.7 & -- \\
\hline & $50-65$ & 19.8 & 17.3 & 17.7 & 17.0 & 16.4 & 15.6 & 14.9 & 14.4 & 14.2 & -- \\
\hline & $65+-$ & 0.7 & 0.8 & 0.8 & 0.6 & 0.5 & 0.5 & 0.5 & 0.4 & 0.4 & -- \\
\hline \multirow[t]{4}{*}{ Verenigde Staten } & $15-24$ & 23.0 & 23.7 & 22.9 & -- & 21.1 & 20.2 & 19.8 & 19.2 & 18.3 & 17.6 \\
\hline & $25-49$ & 54.6 & 55.2 & 56.3 & -- & 58.9 & 58.8 & 60.6 & 61.5 & 61.3 & 61.9 \\
\hline & $50-65$ & 19.3 & 18.4 & 18.1 & -- & 17.6 & 17.1 & 17.0 & 16.8 & 16.4 & 16.4 \\
\hline & $65+-$ & 3.0 & 2.7 & 2.5 & -- & 2.2 & 2.5 & 2.6 & 2.6 & 2.7 & 2.7 \\
\hline \multirow[t]{4}{*}{ Japan } & $15-24$ & 12.4 & 12.3 & 12.2 & 12.4 & 12.4 & 12.3 & 12.5 & 12.6 & 12.7 & 12.9 \\
\hline & $25-49$ & 61.6 & 61.3 & 60.9 & 60.1 & 59.8 & 59.3 & 58.6 & 58.1 & 57.5 & 57.1 \\
\hline & $50-65$ & 21.0 & 21.4 & 22.0 & 22.5 & 22.9 & 23.4 & 23.8 & 24.2 & 24.6 & 24.6 \\
\hline & $65+-$ & 4.9 & 5.0 & 5.0 & 5.0 & 5.0 & 5.0 & 5.0 & 5.1 & 5.3 & 5.4 \\
\hline
\end{tabular}


Tabel 6. Ontwikkeling van de afhankelijkheidsgraad in 7 industrielanden

\begin{tabular}{lllllllll}
\hline & $\begin{array}{l}1950 \\
\%\end{array}$ & $\begin{array}{l}1960 \\
\%\end{array}$ & $\begin{array}{l}1970 \\
\%\end{array}$ & $\begin{array}{l}1980 \\
\%\end{array}$ & $\begin{array}{l}1990 \\
\%\end{array}$ & $\begin{array}{l}2000 \\
\%\end{array}$ & $\begin{array}{l}2010 \\
\%\end{array}$ & $\begin{array}{l}2020 \\
\%\end{array}$ \\
& & & & & & & & \\
& & & & & & & & \\
Nederland & 58.9 & 63.9 & 59.9 & 51.1 & 44.9 & 47.0 & 46.8 & 53.2 \\
Frankrijk & 51.7 & 61.3 & 60.5 & 56.9 & 51.2 & 53.3 & 51.3 & 57.9 \\
West-Duitsland & 48.6 & 47.5 & 57.1 & 50.8 & 43.8 & 48.7 & 52.9 & 56.4 \\
Verenigd Koninkrijk & 49.4 & 53.7 & 59.2 & 56.2 & 52.4 & 53.3 & 50.7 & 54.8 \\
Zweden & 50.8 & 51.4 & 52.7 & 56.0 & 54.8 & 55.7 & 55.3 & 60.7 \\
Verenigde Staten & 54.0 & 67.4 & 61.4 & 51.1 & 51.6 & 49.3 & 47.4 & 55.3 \\
Japan & 67.8 & 56.1 & 45.1 & 48.4 & 43.2 & 48.8 & 58.4 & 63.9 \\
\hline
\end{tabular}

Bron: United Nations/ROA; 1991

Figuur 1. Afhankelijkheidsgraad in de twaalf lidstaten van de Europese Gemeenschap: 1985, 2025

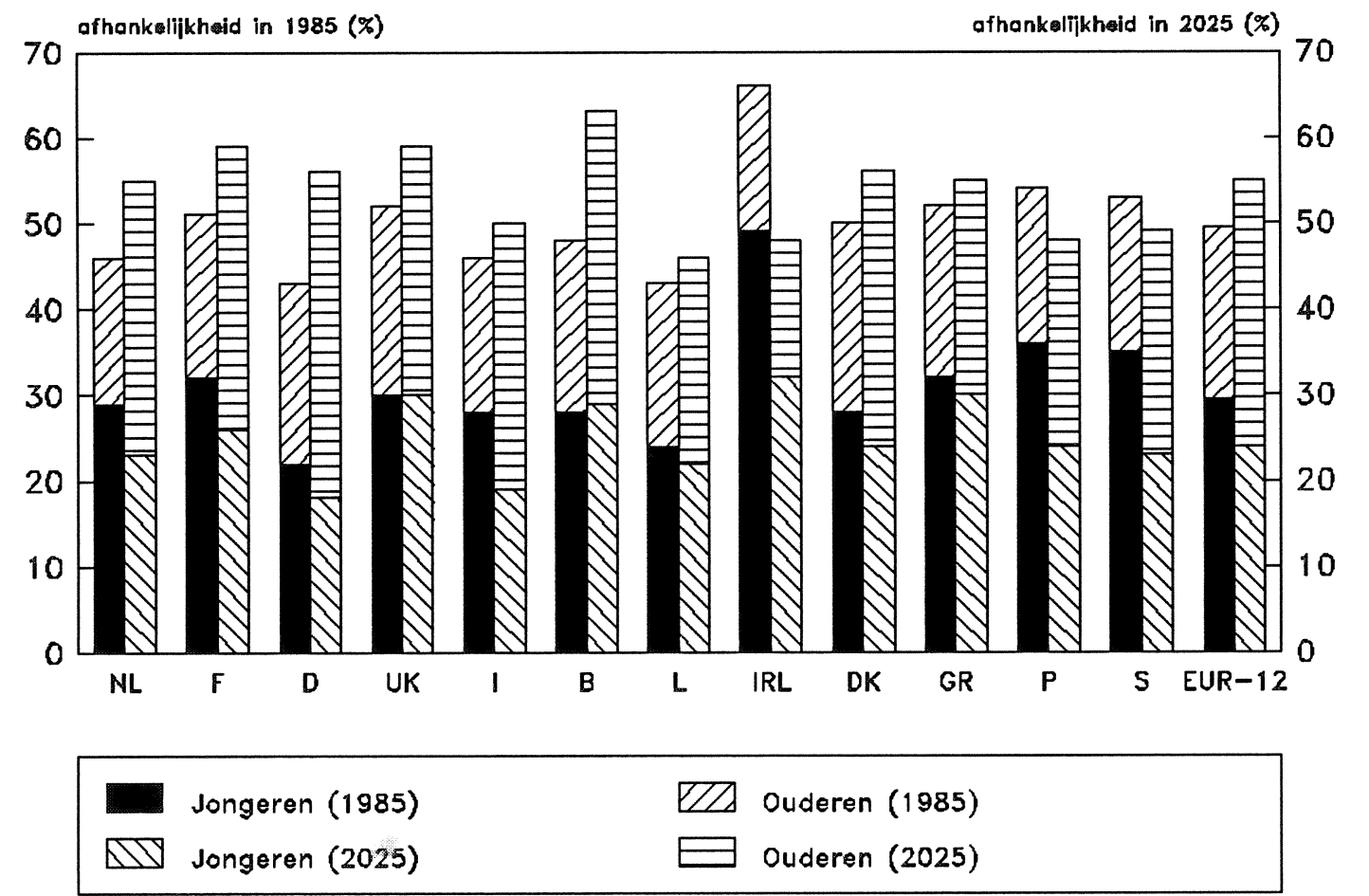

Bron : Eurostat 


\subsection{Scholingsinspanningen}

\subsubsection{Aandeel van de potentiële beroepsbevolking dat scholing volgt}

Scholing is een belangrijk middel om in te spelen op technologische ontwikkelingen. De Labour Force Survey, die jaarlijks door de Europese Gemeenschap wordt georganiseerd, levert gegevens op over het onderwijs dat in de vier weken voorafgaand aan de survey wordt gevolgd. In deze survey wordt aan personen tussen de 15 en 50 jaar gevraagd naar het soort onderwijs dat wordt gevolgd en het doel van het onderwijs. Op basis van deze gegevens kan het aandeel van de potentiële beroepsbevolking tussen de 15 en 50 jaar dat scholing volgt worden samengesteld. Deze indicator kan in enge en in ruime zin worden berekend. Onder scholing in ruime zin wordt dan verstaan 'on the job training, apprenticeship, dual system' en 'other training'. Tot deze indicator worden derhalve alle soorten scholing gerekend die worden gecombineerd met een baan (zie tabel 7). De indicator in enge zin (zie tabel 8) beperkt zich daarentegen tot 'on the job training'. De meer initiële beroepsscholing (apprenticeship e.d.) valt dan buiten de indicator. De indicatoren zijn berekend door het aantal mensen dat de vier weken voorafgaand aan de survey scholing heeft gevolgd te relateren aan de totale bevolking tussen de 15 en 49 jaar. Deze indicatoren kunnen worden gerekend tot de wetenschappelijke en technologische voedingsbodem voor met name de diffusie van technologische ontwikkelingen.

Tabel 7. Scholingsparticipatie van de potentiële beroepsbevolking 15-49 jaar (in ruime zin)

\begin{tabular}{|c|c|c|c|c|c|c|c|}
\hline & $\begin{array}{c}1983 \\
\%\end{array}$ & $\begin{array}{c}1984 \\
\%\end{array}$ & $\begin{array}{c}1985 \\
\%\end{array}$ & $\begin{array}{c}1986 \\
\%\end{array}$ & $\begin{array}{c}1987 \\
\%\end{array}$ & $\begin{array}{c}1988 \\
\%\end{array}$ & $\begin{array}{c}1989 \\
\% \\
\end{array}$ \\
\hline Nederland & 5 & -- & 5 & -- & 6 & 7 & 7 \\
\hline West-Duitsland & -- & 5 & 7 & 8 & 8 & 9 & 8 \\
\hline Verenigd Koninkrijk & 7 & 7 & 7 & 7 & 8 & 9 & 10 \\
\hline Italië & 1 & 1 & 1 & 1 & 2 & 2 & 2 \\
\hline België & 2 & 2 & 2 & 2 & 2 & 1 & 2 \\
\hline Luxemburg & 3 & 3 & 3 & 3 & 3 & 3 & 2 \\
\hline lerland & 3 & 3 & 3 & 3 & 3 & -- & 3 \\
\hline Denemarken & -- & 13 & 15 & 15 & 16 & 14 & 10 \\
\hline Griekenland & 1 & 1 & 1 & 1 & 1 & 1 & 1 \\
\hline
\end{tabular}

Bron: Eurostat/ROA

Tabel 7 laat zien dat de scholingsparticipatie in ruime zin in Denemarken en het Verenigd Koninkrijk het hoogst is, gevolgd door West-Duitsland en Nederland. In de andere landen (met name Griekenland) is de scholingsparticipatie extreem laag. In de meeste landen blijft in de periode 1983-1989 het niveau van de scholingsparticipatie min of meer constant. In het Verenigd Koninkrijk is in de tweede helft van de jaren tachtig een stijgende tendens waarneembaar. 
De daling die zich in Denemarken in 1988 voor het eerst heeft aangediend, zet zich in 1989 voort.

Tabel 8. Scholingsparticipatie van de potentiële beroepsbevolking 15-49 jaar (in enge zin)

\begin{tabular}{|c|c|c|c|c|c|c|c|}
\hline & $\begin{array}{c}1983 \\
\%\end{array}$ & $\begin{array}{c}1984 \\
\% \\
\end{array}$ & $\begin{array}{c}1985 \\
\% \\
\end{array}$ & $\begin{array}{c}1986 \\
\% \\
\end{array}$ & $\begin{array}{c}1987 \\
\% \\
\end{array}$ & $\begin{array}{c}1988 \\
\%\end{array}$ & $\begin{array}{c}1989 \\
\% \\
\end{array}$ \\
\hline Nederland & 2 & -- & 2 & -- & 2 & 2 & 2 \\
\hline West-Duitsland & - & 0 & 0 & 0 & 1 & 1 & 1 \\
\hline Verenigd Koninkrijk & 1 & 2 & 2 & 2 & 2 & 2 & 3 \\
\hline Italië & 0 & 0 & 0 & 0 & 0 & 0 & 0 \\
\hline België & 1 & 1 & 1 & 1 & 1 & 0 & 0 \\
\hline Luxemburg & 1 & 0 & 0 & 0 & 1 & 1 & 1 \\
\hline lerland & 2 & 2 & 2 & 2 & 2 & 0 & 2 \\
\hline Denemarken & 2 & 2 & 3 & 4 & 3 & 4 & 3 \\
\hline Griekenland & ـ & مـ & مـ & ـــ & 0 & 0 & 0 \\
\hline
\end{tabular}

Bron: Eurostat/ROA

In tabel 8 wordt de scholingsparticipatie in enge zin weergegeven. Alleen de 'on the job training' wordt hierbij in beschouwing genomen. Het verloop van deze indicator komt grotendeels overeen met dat van de indicator in ruime zin. Ook hier zijn Denemarken en het Verenigd Koninkrijk koplopers, echter nu gevolgd door Nederland en lerland. Opvallend is hier echter de relatief lage scholingsparticipatie in West-Duitsland (een land dat vooral bekend is om het goed ontwikkelde initiële duale onderwijs).

Weliswaar maken de hier gepresenteerde indicatoren een vergelijking met andere landen mogelijk, maar deze internationale vergelijkbaarheid beperkt zich vooralsnog tot de lidstaten van de Europese Gemeenschap.

\subsubsection{Aandeel van werknemers met een leerovereenkomst per bedrijfssector}

In deze subparagraaf wordt een nieuwe indicator gepresenteerd die per bedrijfssector het percentage primaire (tabel 9) dan wel voortgezette (tabel 10) leerovereenkomsten weergeeft. Deze nieuwe indicator is samengesteld op basis van gegevens over het aantal primaire leerovereenkomsten per opleidingstelsel uit het leerlingwezen (verstrekt door de opleidingsorganen) en verzameld door het CBS en de gegevens over het arbeidsvolume per bedrijfssector. Deze laatsgenoemde data worden jaarlijks verstrekt door het Centraal Planbureau (Centraal Economisch Plan 1990). Om het arbeidsvolume dat wordt ingenomen door leerlingwerknemers te berekenen, wordt een leerovereenkomst beschouwd als een baan waarbij men $80 \%$ van een vijfdaagse werkweek werkt. Derhalve is het aantal leerovereenkomsten 
vermenigvuldigd met de werktijdfactor 0.8 . In het leerlingstelsel wordt immers én werkdag op school doorgebracht.

De indicator is berekend voor zeven, door het Centraal Orgaan van de Regionale Organen voor het leerlingwezen (CORO) onderscheiden, sectoren. Het arbeidsvolume per sector wordt bepaald door arbeidsvolumina van een aantal corresponderende CPB-bedrijfssectoren op te tellen. Het aantal primaire leerovereenkomsten per sector wordt bepaald door de primaire leerovereenkomsten van verschillende opleidingsorganen te aggregeren. De getallen in de tabel geven per sector het procentueel deel van het arbeidsvolume weer dat wordt ingenomen door werknemers met een primaire leerovereenkomst.

In bijlage I wordt weergegeven welke bedrijfssectoren van het CPB zijn gekoppeld aan de sectoren van het CORO. Tevens wordt aangegeven welke opleidingsorganen uit de data van het CBS geaggregeerd worden tot de sectoren van het CORO.

Tabel 9. Aandeel van primaire leerovereenkomsten in het arbeidsvolume per bedrijfssector (\%)

\begin{tabular}{lllllllll}
\hline Sector & 1965 & 1970 & 1975 & 1980 & 1985 & 1986 & 1987 & 1988 \\
\hline & & & & & & & & \\
Metaal en electro & 6.4 & 5.8 & 3.7 & 5.1 & 5.0 & 6.2 & 7.0 & 7.0 \\
Bouw en hout & 2.6 & 2.0 & 0.9 & 1.9 & 1.9 & 2.2 & 2.3 & 2.4 \\
Consumptief & 1.9 & 2.1 & 1.9 & 2.9 & 3.4 & 3.7 & 4.0 & 4.4 \\
Procestechniek & 0.5 & 0.6 & 0.5 & 0.9 & 1.4 & 2.2 & 2.0 & 1.8 \\
Grafisch & 2.6 & 2.0 & 0.7 & 1.6 & 1.2 & 1.5 & 1.8 & 1.8 \\
Transport & 0.2 & 0.1 & 0.2 & 0.3 & 0.5 & 0.6 & 0.6 & 0.7 \\
Textiel en kleding & -- & 1.0 & 0.7 & 0.9 & 1.8 & 2.2 & 2.1 & 2.2 \\
\hline
\end{tabular}

Bron: CBS/CPB/ROA; 1991

Legenda: -- niet aanwezig

In tabel 9 komt naar voren dat het aandeel van primaire leerovereenkomsten in de sector metaal en electro duidelijk het hoogste is, gevolgd door de consumptieve sector. Alle sectoren geven in de loop van de jaren tachtig een toename van het aantal primaire leerovereenkomsten te zien. De toename is het kleinst in de grafische sector en het grootst in de consumptieve sector en in de sector metaal en electro.

In tabel 10 wordt het aandeel van voortgezette leerovereenkomsten per bedrijfssector weergegeven. Het algehele beeld dat op basis van deze indicator wordt geschetst, komt grotendeels overeen met dat van de primaire leerovereenkomsten. 
$-17-$

Tabel 10. Aandeel van voortgezette leerovereenkomsten in het arbeidsvolume per bedrijfssector (\%)

\begin{tabular}{lllllllll}
\hline Sector & 1965 & 1970 & 1975 & 1980 & 1985 & 1986 & 1987 & 1988 \\
\hline & & & & & & & & \\
Metaal en electro & 0.2 & 0.6 & 0.6 & 1.3 & 1.4 & 1.8 & 2.2 & 2.6 \\
Bouw en hout & 0.6 & 0.6 & 0.4 & 0.4 & 0.6 & 0.7 & 0.8 & 0.9 \\
Consumptief & 0.9 & 0.6 & 0.6 & 1.4 & 1.3 & 1.6 & 1.8 & 2.0 \\
Procestechniek & -- & 0.1 & 0.0 & 0.1 & 0.0 & 0.1 & 0.6 & 1.1 \\
Grafisch & -- & -- & 0.2 & 0.3 & 0.2 & 0.3 & 0.6 & 0.6 \\
Transport & 0.0 & 0.0 & 0.0 & 0.0 & 0.0 & 0.0 & 0.0 & 0.0 \\
Textiel en kleding & 0.1 & 0.0 & 0.0 & 0.0 & 0.2 & 0.1 & 0.1 & 0.2 \\
\hline
\end{tabular}

Bron: CBS/CPB/ROA; 1991

Legenda: -- niet aanwezig 


\section{RESPONS VANUIT HET RELATIENETWERK EN AANVULLENDE DATA- BRONNEN}

\subsection{Mailing en respons vanuit het relatienetwerk}

Evenals vorig jaar is een Engelstalige versie van het rapport, waarin verslag wordt gedaan van het onderzoek uit 1990, verzonden naar een zestigtal onderzoeksinstituten, onderzoekafdelingen van departementen en individuele onderzoekers in het buitenland. Daaraan verbonden was een verzoek om commentaar op het rapport uit 1990 en een verzoek om toezending van voor een nieuwe inventarisatie mogelijk zinvolle cijfers of rapporten. Naast de instituten die in het voorgaande jaar zijn benaderd, is dit jaar aan Eurostat verzocht om de adressen van gebruikers van een aantal variabelen uit de Labour Force Survey. Vervolgens zijn ook deze onderzoekers aangeschreven met een gedetailleerde 'request for information'.

Hoewel er ook dit jaar een groot aantal reacties op deze mailing is binnengekomen, was de direkte bruikbaarheid daarvan voor opname in METING teleurstellend. In Bijlage II is een overzicht opgenomen van de toegezonden publikaties per land en per instituut. Hieruit blijkt dat er in vrijwel ieder van de aangeschreven landen een instituut bestaat dat zich richt op vraagstukken op het terrein van onderwijs, scholing, arbeidsmarkt en beroepsbevolking. Helaas blijken er zeer weinig mogelijkheden te zijn om gegevens van deze instituten onderling te combineren. Dit zal ook de reden zijn dat er op Europees en OECD niveau nog relatief weinig cijfers beschikbaar zijn over de genoemde aspecten.

\subsection{Europese instituten en integratie van dataverzameling}

Er zijn verschillende instanties op Europees of anderszins internationaal niveau werkzaam om landelijke gegevens internationaal te vergelijken c.q. vergelijkbaar te maken.

- Het Europees Centrum voor de Ontwikkeling van Beroepsopleidingen (Cedefop) te Berlijn heeft als officieel orgaan van de Europese Commissie de taak om door onder meer onderzoek en overleg, bij te dragen aan de ontwikkeling van beroepsopleidingen in Europa. In 1990 is een zogeheten 'Flash' verschenen waarin de resultaten van een aantal landenstudies naast elkaar gezet zijn, zodat een redelijk vergelijkbaar overzicht ontstond van kosten en deelname aan bedrijfsopleidingen. Helaas heeft deze eerste Flash nog geen vervolg gehad, hoewel hieraan wel gewerkt zal gaan worden.

- Sinds 1990 bestaat SYSDEM, het European System of Documentation on Employment, dat 
wordt samengesteld door het Engelse bureau Ecotec in opdracht van de Europese Commissie (DG-V). Het verstrekt, middels een kwartaalblad, informatie over de ontwikkeling van (aspecten van) de werkgelegenheid in de EG-lidstaten. De informatie wordt verkregen van nationale correspondenten. Van onderlinge vergelijkbaarheid van de verstrekte informatie is echter nog geen sprake.

- Eenzelfde opzet als SYSDEM heeft het Mutual Information System on Employment Policies (MISEP). Door middel van het kwartaalblad InforMISEP wordt informatie verstrekt over het werkgelegenheidsbeleid in de EG-Lidstaten.

- De International Association for the Evaluation of Educational Achievement (IEA) zal in 1992 van start gaan met de Third International Mathematics Study. De resultaten van het tweede onderzoeksproject werden beschreven in Van Dam en De Grip (1990). Coördinatie van het Nederlandse onderzoek zal plaatsvinden vanuit de Faculteit der Toegepaste Onderwijskunde van de Universiteit Twente. In 1994 zal het International Foreign Languages Project van start gaan. Coördinatie van het gehele project zal waarschijnlijk in handen zijn van de Universiteit van Amsterdam.

- Binnen het Bureau voor de Statistiek van de Europese Gemeenschappen (EUROSTAT) is de Afdeling E-1: Statistiques d'Emploi et Chomage, Education et Formation, belast met de ontwikkeling van onderzoeken en bijbehorende protocollen, classificaties en dergelijke, op het terrein van arbeidsmarkt, scholing en beroepsbevolking. De uitvoering van deze onderzoeken is in handen van de nationale Statistische Bureaus van de lidstaten. Vooralsnog is het echter alleen de Labour Force Survey die jaarlijks wordt uitgevoerd (vanaf 1992 met de toevoeging van enkele nieuwe variabelen). De ontwikkeling van een gezamenlijke onderwijsstatistiek stokt nog steeds op een hanteerbare onderwijsclassificatie.

Door Eurostat is thans ook een begin gemaakt met de ontwikkeling van prognoses voor bevolking, beroepsbevolking en arbeidsmarkt. In het kader hiervan is een inventarisatie gemaakt van instituten in de lidstaten die zich bezighouden met het opstellen van desbetreffende nationale en regionale prognoses. In vrijwel alle landen van de Europese Gemeenschap worden de prognoses voor de beroepsbevolking opgesteld door een (semi) overheidsinstantie. Eurostat zal zich in eerste instantie richten op het harmoniseren en opstellen van bevolkingsprognoses. In een tweede fase zullen arbeidsaanbodprognoses worden opgesteld. De prognoses zullen naar verwachting twee-jaarlijks worden opgesteld met een dertig-jarige prognosetermijn en in een drietal varianten. De voorstellen die hierop betrekking hebben, zullen op een Eurostat-congres in het najaar van 1991 gepresenteerd en besproken worden. 


\subsection{Incidentele onderzoeken}

\subsubsection{Talenkennis en talenbehoefte}

Als gevolg van de Europese integratie, ontstaat er in toenemende mate behoefte aan kennis van vreemde talen. Tegelijkertijd lijkt Nederland haar internationale reputatie op het terrein van de talenkennis te verliezen.

Om de ontwikkelingen met betrekking tot de talenkennis in kaart te brengen is een vijftal indicatoren geconstrueerd. Deze zouden inzicht moeten geven in de verhouding tussen de feitelijke talenkennis en de behoefte aan talenkennis. Daarbij doet zich het probleem voor dat de behoefte aan talenkennis moeilijk meetbaar is, terwijl ook over de feitelijke kennis nauwelijks gegevens voorhanden zijn (Van Hest e.a., 1990). Bovendien zouden de indicatoren zowel voor meerdere landen als voor verschillende jaren berekend moeten worden, ten einde zinvolle uitspraken te kunnen doen over de ontwikkeling van de 'concurrentiepositie' van Nederland. De beschikbare data maken het mogelijk incidenteel indicatoren samen te stellen over:

1. De omvang van de Nederlandse export naar diverse taalgebieden.

2. De (vermeende) behoefte aan kennis van vreemde talen door bedrijven in Nederland.

3. Het gebruik van Engels, Duits en Frans door zakenlieden met contacten in het buitenland.

4. De gesignaleerde problemen binnen het Nederlandse bedrijfsleven met betrekking tot het gebruik van vreemde talen.

5. Het aantal geleerde en correct gesproken talen door de bevolking van verscheidene Europese landen.

De eerste indicator betreft de Nederlandse export naar diverse taalgebieden.

Tabel 11. Nederlandse export naar taalgebied (\%)

\begin{tabular}{ccc} 
Taalgebied & \multicolumn{2}{c}{ Aandeel in de export in } \\
& 1977 & 1987 \\
$\%$ & $\%$
\end{tabular}

Duitstalige gebieden 
Uit tabel 11 blijkt dat Duitstalige gebieden onze belangrijkste exportpartners zijn. Daarom lijkt de conclusie gerechtvaardigd om Duits als belangrijkste taal te zien, tenminste wat handelscontacten betreft. Daarmee enigszins in contrast zijn de cijfers over de behoefte aan vreemde talen die door de bedrijven wordt opgegeven. Uiteraard hebben bedrijven behoefte aan talenkennis voor meer doeleinden dan alleen internationale handelscontacten. Deze tweede indicator wordt weergegeven in tabel 12.

Tabel 12. Behoefte aan kennis van vreemde talen in het Nederlandse bedrijfsleven (\%)*

\begin{tabular}{lrr}
\hline & $\begin{array}{r}1978 \\
\%\end{array}$ & $\begin{array}{r}1988 \\
\%\end{array}$ \\
\hline Engels & 64 & 89 \\
Frans & 49 & 53 \\
Duits & 65 & 64 \\
Spaans & $(-)$ & 19 \\
overige & 11 & 5 \\
aantal bedrijven & 641 & 231 \\
\hline
\end{tabular}

* Cijfers n.a.v. de vraag: "Aan welke vreemde talen is er bij uw bedrijf behoefte?"

(-) Gerekend onder 'overige'

Bron: Koster (1990), blz. 3

Uit tabel 12 blijkt dat de behoefte aan Engels en Spaans zeer sterk is gestegen, terwijl de behoefte aan Duits en Frans betrekkelijk constant is gebleven. De stijging van de behoefte aan talenkennis is eveneens geconstateerd door Raadgevend Bureau Claessens. Dit bureau onderzoekt jaarlijks de functie-eisen die in personeelsadvertenties gesteld worden. Uit deze onderzoeken blijkt dat het percentage advertenties waarin talenkennis vereist wordt, in de periode $1987-1989$ is gestegen van $20 \%$ tot $27 \%$.

Tabel 13a. Percentages zakenlieden die zich enigermate in het Engels, Frans en Duits kunnen uiten

\begin{tabular}{lcrr}
\hline & $\begin{array}{c}\text { Engels } \\
\%\end{array}$ & $\begin{array}{r}\text { Frans } \\
\%\end{array}$ & $\begin{array}{r}\text { Duits } \\
\%\end{array}$ \\
& & & \\
& & 20 & 50 \\
Nederland & 79 & 100 & 100 \\
Frankrijk & 27 & 15 & 4 \\
West-Duitsland & 32 & 8 & 40 \\
Verenigd Koninkrijk & 100 & 20 & 2 \\
Italië & 23 & 18 & \\
Spanje & 20 & & \\
\end{tabular}

Bron: European Businessman Readership Survey 1984, in: VU-Talencentrum (1990) 
Tabel 13b. De talen Engels, Frans of Duits waarin zakenlieden zich enigermate kunnen uiten (\%)

\begin{tabular}{lcccccc}
\hline & geen & 1 taal & 2 talen & 3 talen & gemiddeld & $\begin{array}{c}\text { indicator } \\
\text { (=gem/1.43) } \\
\%\end{array}$ \\
& $\%$ & $\%$ & $\%$ & $\%$ & & 79 \\
\hline $\begin{array}{l}\text { Verenigd Koninkrijk } \\
\text { Frankrijk }\end{array}$ & 0 & 88 & 11 & 0 & 1,12 & 93 \\
West-Duitsland & 0 & 69 & 29 & 1 & 1,32 & 103 \\
Nederland & 0 & 58 & 37 & 5 & 1,47 & 100 \\
Italië & 10 & 44 & 40 & 6 & 1,43 & 62 \\
Spanje & 37 & 39 & 22 & 2 & 0,89 & 30 \\
\hline
\end{tabular}

Bron: ROA/European Businessman Readership Survey 1984, in: VU-Talencentrum (1990)

De derde indicator wordt weergegeven in tabel 13. Voor een aantal landen is nagegaan of zakenlieden met internationale contacten zich enigermate kunnen uiten in de drie belangrijkste handelstalen binnen de Europese Gemeenschap, namelijk Engels, Duits en Frans. Hierbij dient te worden bedacht dat Engelsen, Fransen en Duitsers in het internationale handelsverkeer een natuurlijk voordeel hebben, daar zij allemaal hun moedertaal spreken. Van deze drie volkeren beheersen West-Duitsers nog het vaakst een vreemde taal (zie tabel 13a). Van de andere volkeren zijn het vooral de Nederlanders die zich in Frans, Duits, of Engels kunnen uiten. De Spanjaarden kunnen dit het minst vaak. Het aantal talen (Frans, Duits of Engels) waarin men zich kan uiten staat vermeld in tabel 13b. Hierin komt naar voren dat Nederlandse zakenlieden het wat dit betreft erg goed doen. De kolom met indicatoren geeft aan dat alleen WestDuitsland beter scoort dan Nederland. West-Duitse zakenlieden hebben daarbij ten opzichte van Nederlanders het voordeel dat hun moedertaal behoort tot één van de drie belangrijkste handelstalen binnen Europa. Spanje scoort erg slecht.

De vierde indicator wordt weergegeven in tabel 14 . Bij alle vreemde talen worden in toenemende mate problemen bij met name het spreken en schrijven geconstateerd. De problemen met betrekking tot de uitdrukkingsvaardigheid in woord en geschrift worden bij het Frans het vaakst gesignaleerd, terwijl er een sterke stijging is van problemen bij vooral Duits en Engels in de periode 1978-1988. 
Tabel 14. Problemen bij het gebruik van Engels, Frans en Duits in het Nederlandse bedrijfsleven (\%)

\begin{tabular}{lrlc}
\hline & 1978 & 1988 \\
\hline Frans & 72 & $\begin{array}{l}\text { vnl. bij luisteren, } \\
\text { spreken en schrijven } \\
\text { vnl. bij spreken en } \\
\text { schrijven } \\
\text { vnl. bij spreken en } \\
\text { schrijven }\end{array}$ & 86 \\
Duits & 41 & 68 \\
Engels & 641 & 231 \\
aantal bedrijven & 42 & 72 \\
\hline
\end{tabular}

Bron: Koster (1990), blz. 7

De vijfde indicator (tabel 15) geeft een beeld van het aantal vreemde talen dat de bevolkingen van landen van de Europese Gemeenschap op school hebben geleerd en het aantal vreemde talen dat correct wordt gesproken. Behalve voor de gehele bevolking, worden de cijfers ook voor jongeren weergegeven. In landen die behoren tot de kleinere taalgebieden (met name de Beneluxlanden en Denemarken) wordt veel aandacht besteed aan het leren van vreemde talen. Dit heeft tot gevolg dat ook de mondelinge beheersing van vreemde talen in deze landen beter is dan in de grotere landen. $\mathrm{Er}$ is overigens bij alle landen sprake van discrepantie tussen het leren van een vreemde taal en de mondelinge uitdrukkingsvaardigheid in een vreemde taal. In tabel 15 komt verder duidelijk naar voren dat in alle landen van de EG de talenkennis toeneemt. Jongeren leren en beheersen meer vreemde talen dan bij ouderen het geval is. Wel neemt de effectiviteit van het taalonderwijs af. De discrepantie tussen leren en mondeling beheersen van een vreemde taal is bij jongeren groter dan bij ouderen.

Geconcludeerd kan worden dat Nederland binnen de Europese Gemeenschap qua talenkennis nog steeds behoort tot de koplopers. Overigens neemt, evenals in de meeste andere landen het geval is, de (zelf ervaren) effectiviteit van het taalonderwijs af. Dit heeft geleid tot een toename van problemen met betrekking tot de mondelinge en schriftelijke beheersing van vreemde talen.

\section{Toekomst}

Hoewel de omvang van het onderwijs in vreemde talen (geoperationaliseerd door het aantal vreemde talen dat geleerd wordt) in Nederland is toegenomen, blijft de mondelinge beheersing van vreemde talen hierbij achter. In hoeverre Nederland zal slagen haar traditionele voorsprong in talenkennis te behouden hangt af van de aandacht die aan de kwaliteit van het vreemde talenonderwijs wordt gegeven. 
Tabel 15. Het aantal op school geleerde talen en het aantal correct gesproken talen, met uitzondering van de moedertaal

\begin{tabular}{lcccc}
\hline & $\begin{array}{l}\text { Geleerde } \\
\text { talen }\end{array}$ & $\begin{array}{l}\text { Jeugd } \\
\text { Correct } \\
\text { gesproken } \\
\text { talen }\end{array}$ & $\begin{array}{l}\text { Gehele bevolking } \\
\text { Geleerde } \\
\text { talen }\end{array}$ & $\begin{array}{l}\text { Correct } \\
\text { gesproken } \\
\text { talen }\end{array}$ \\
\hline Nederland & 2.6 & 1.6 & 2.1 & 1.3 \\
Frankrijk & 1.8 & 0.7 & 1.1 & 0.4 \\
West-Duitsland & 1.4 & 0.9 & 0.9 & 0.5 \\
Verenigd Koninkrijk & 1.2 & 0.4 & 0.8 & 0.3 \\
Luxemburg & 3.1 & 2.7 & 2.7 & 2.4 \\
Denemarken & 2.5 & 1.4 & 1.9 & 1.0 \\
België & 2.0 & 1.0 & 1.4 & 0.9 \\
lerland & 1.5 & 0.4 & 0.9 & 0.3 \\
Portugal & 1.4 & 0.6 & 0.7 & 0.4 \\
Italie & 1.3 & 0.5 & 0.8 & 0.3 \\
Spanje & 1.1 & 0.6 & 0.6 & 0.4 \\
Griekenland & 1.0 & 0.7 & 0.6 & 0.4 \\
Eur12 & 1.5 & 0.7 & 1.0 & 0.5 \\
\hline
\end{tabular}

Bron: Wordelmann (1991), blz. 34

\subsubsection{Schoolgang en werkloosheid bij jongeren in Europa}

Door het Duitse Institut für Arbeitsmarkt- und Berufsforschung (IAB) zijn cijfers verzameld over de onderwijsparticipatie en werkloosheid van verschillende leeftijdscategoriën jongeren in de Europese Gemeenschap (IAB, 1990).

\section{Onderwijsparticipatie van jongeren}

In figuur 2 worden EG-cijfers weergegeven over de participatie van jongeren in het reguliere onderwijs. Hieruit blijkt de relatief sterke positie van de onderwijsdeelname in West-Duitsland, Denemarken en Nederland. De onderwijsparticipatie van Nederlandse 24-jarigen wijkt niet significant af van het Europese beeld: respectievelijk $9.1 \%$ en $9.4 \%$. In de begeleidende tekst van het IAB wordt niet duidelijk gemaakt waarom de cijfers van het Verenigd Koninkrijk voor de 21- en 24-jarigen ontbreken. 
Figuur 2. Schoolparticipatie voor verschillende leeftijdscategorieën in de EG (\%)

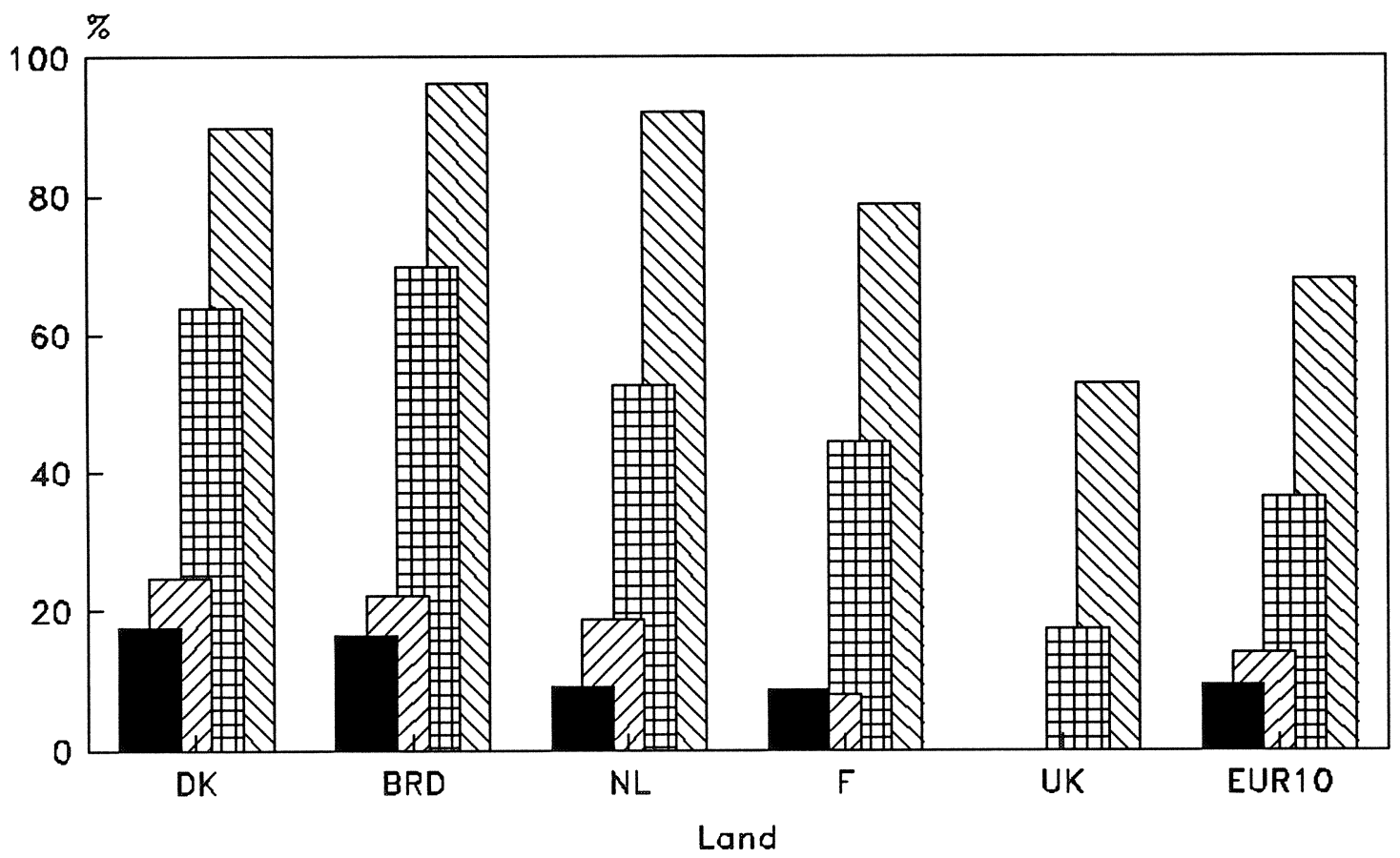

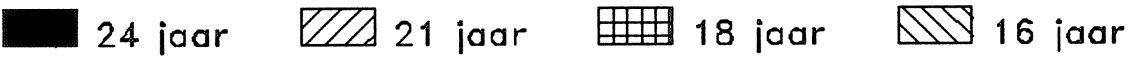

Bron : West-Duitsland:IAB/BGR; voor de andere landen: EG-Commissie (1988)

IAB : Institut für Arbeitsmarkt und Berufsforschung

BGR : Bildungsgesamtrechnung

Jeugdwerkloosheid in de EG

In Tabel 16 en figuur 3 worden EG-cijfers gepresenteerd over de jeugdwerkloosheid. Deze zijn eveneens afkomstig uit de hiervoor genoemde IAB-publikatie.

Figuur 3 toont duidelijk aan dat de jeugdwerkloosheid in Nederland in 1985 tot de relatief laagsten van Europa behoorde. Uit tabel 16 blijkt dat er in 1985 in Nederland iets meer jongens dan meisjes werkloos waren in tegenstelling tot de meeste andere landen van de Europese Gemeenschap, waar de jeugdwerkloosheid onder meisjes aanzienlijk groter is dan onder jongens. Een derde opmerking betreft de verhouding tussen de jeugdwerkloosheid en de werkloosheid onder de gehele beroepsbevolking (waarvoor hier overigens geen cijfers worden gegeven). De Nederlandse werkloosheid behoort al jaren tot de hoogste van de Europese Gemeenschap. Voor wat betreft de jeugdwerkloosheid is hiervan echter geenszins sprake. 
$-26-$

Tabel 16. Werkloosheidspercentages in de leeftijdsklasse 14-24 jaar in de EG, 1985

\begin{tabular}{lccc}
\hline & & & \\
Land & man & vrouw & totaal \\
\hline & & & 17.7 \\
Nederland & 18.7 & 16.7 & 25.8 \\
Frankrijk & 22.9 & 28.8 & 9.9 \\
West-Duitsland & & & 14 \\
- met leerlingen duale stelsel & 8.8 & 11.3 & 19.9 \\
- zonder leerlingen duale stelsel & 12.8 & 15.4 & 23.6 \\
Verenigd Koninkrijk & 15.1 & 25.8 & 11.5 \\
België & 17.7 & 29.8 & 23.9 \\
Denemarken & 10 & 13.2 & 25.1 \\
Griekenland & 17.5 & 31.7 & 31.7 \\
lerland & 26.4 & 23.4 & 6.5 \\
Italië & 26 & 38.6 & 18.2 \\
Luxemburg & 6.4 & 6.5 & 48.1 \\
Portugal & 19.6 & 16.6 & 50.8 \\
Spanje & 46.1 & & \\
\hline
\end{tabular}

Figuur 3. Werkloosheidspercentages in de leeftijdsklasse 14-24 jaar in de EG, 1985

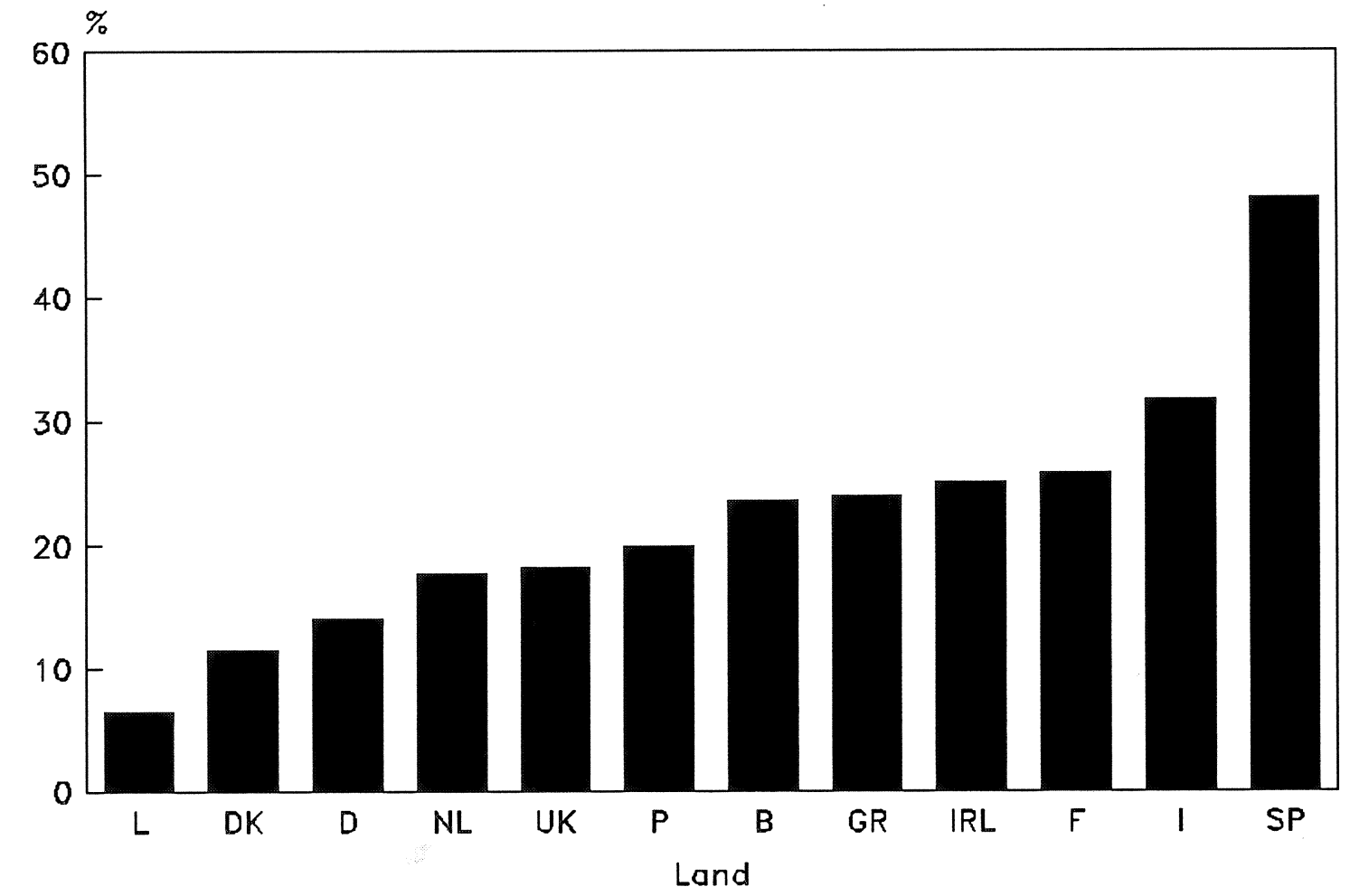

Bron : West-Duitsland:IAB/BGR; voor de andere landen: EG-Commissie (1988)

IAB : Institut für Arbeitsmarkt und Berufsforschung

BGR : Bildungsgesamtrechnung 


\subsubsection{IRDAC-rapportage over kwalificatietekorten in Europa}

In opdracht van het Industrial Research and Development Advisory Committee (IRDAC) van de Europese Commissie is een rapport samengesteld over kwalificatietekorten in Europa (IRDAC, 1991). Tabel 17 is overgenomen uit dit rapport.

De tabel, die enkel een indicatieve waarde heeft, is samengesteld op basis van een groot aantal bronnen die over het algemeen verwijzen naar de situatie in het begin van de jaren ' 80 . Voor de interpretatie van de tabel wordt opgemerkt dat de eerste kolommen alleen betrekking hebben op universiteiten en niet op andere vormen van hoger onderwijs, zoals Fachhochschulen en Hogescholen. De tabel maakt duidelijk dat er grote verschillen zijn tussen de lidstaten. Hierbij dient te worden bedacht dat in sommige landen de ingenieurs en technici uit niet-universitaire instellingen een gedeelte van het onderscheid kunnen goedmaken. De eerste kolommen wijzen op grote verschillen in het aandeel van de ingenieursdisciplines en de exacte wetenschappen binnen het universitaire onderwijs. In alle Europese landen, op Frankrijk en het Verenigd Koninkrijk na, hebben de ingenieursdisciplines een groter aandeel dan de exacte wetenschappen (dit wordt echter in het Verenigd Koninkrijk gecompenseerd door de ingenieursopleiding binnen de niet-universitaire polytechnics en in Frankrijk door de niet-universitaire technici). De verschillen tussen het aandeel van ingenieursdisciplines en het aandeel van exacte wetenschappen zijn overigens nergens zo groot als in Japan waar er 6 maal meer ingenieurs zijn dan exacte wetenschappers.

Tabel 17. Indicatoren voor de relatieve betekenis van ingenieursdisciplines en exacte wetenschappen in het universitair onderwijs en van ingenieurs in de beroepsbevolking

\begin{tabular}{|c|c|c|c|}
\hline $\begin{array}{l}\text { Aandeel ingenieurs- } \\
\text { disciplines in } \\
\text { universitair onderwijs } \\
\text { (\%studenten) }\end{array}$ & $\begin{array}{l}\text { Aandeel exacte } \\
\text { wetenschappen in } \\
\text { universitair onderwijs } \\
\text { (\% studenten) }\end{array}$ & Totaal & $\begin{array}{l}\text { Aandeel } \\
\text { ingenieurs in } \\
\text { de beroepsbe- } \\
\text { volking (in \%) }\end{array}$ \\
\hline
\end{tabular}

$\begin{array}{lrrrr}\text { Nederland } & 16.3 & 12.0 & 28.3 & 1.8 \\ \text { Frankrijk } & 7.1 & 12.9 & 18.7 & 1.2 \\ \text { West-Duitsland } & 14.1 & 18.1 & 32.2 & 2.2 \\ \text { Verenigd Koninkrijk } & 16.7 & 22.8 & 39.3 & 1.0 \\ \text { EUR12 } & 15.0 & 13.0 & 28.0 & 1.4 \\ \text { Japan } & 21.6 & 3.2 & 24.8 & 2.5 \\ \text { USA } & 5.9 & 11.6 & 17.5 & 1.4\end{array}$

Bron: IRDAC (1991)

De laatste kolom geeft het aandeel van de ingenieurs (met diploma's van universiteiten of 
hogescholen) binnen de totale beroepsbevolking weer. Hier zien we significante verschillen: sommige lidstaten hebben wel tweemaal zoveel ingenieurs als andere landen. Door de bank genomen bevindt Europa zich ongeveer op hetzelfde niveau als de Verenigde Staten, maar blijft sterk achter ten opzichte van Japan (IRDAC, 1991, blz. 37/38).

Ten behoeve van het IRDAC-rapport is door MERIT een onderzoek verricht naar mogelijke kwalificatietekorten in Europa. In het IRDAC-rapport is op pagina 20 de volgende figuur uit dit onderzoek opgenomen.

Figuur 4. Voorspelde vraag naar opleidingscategorieën in de jaren '90

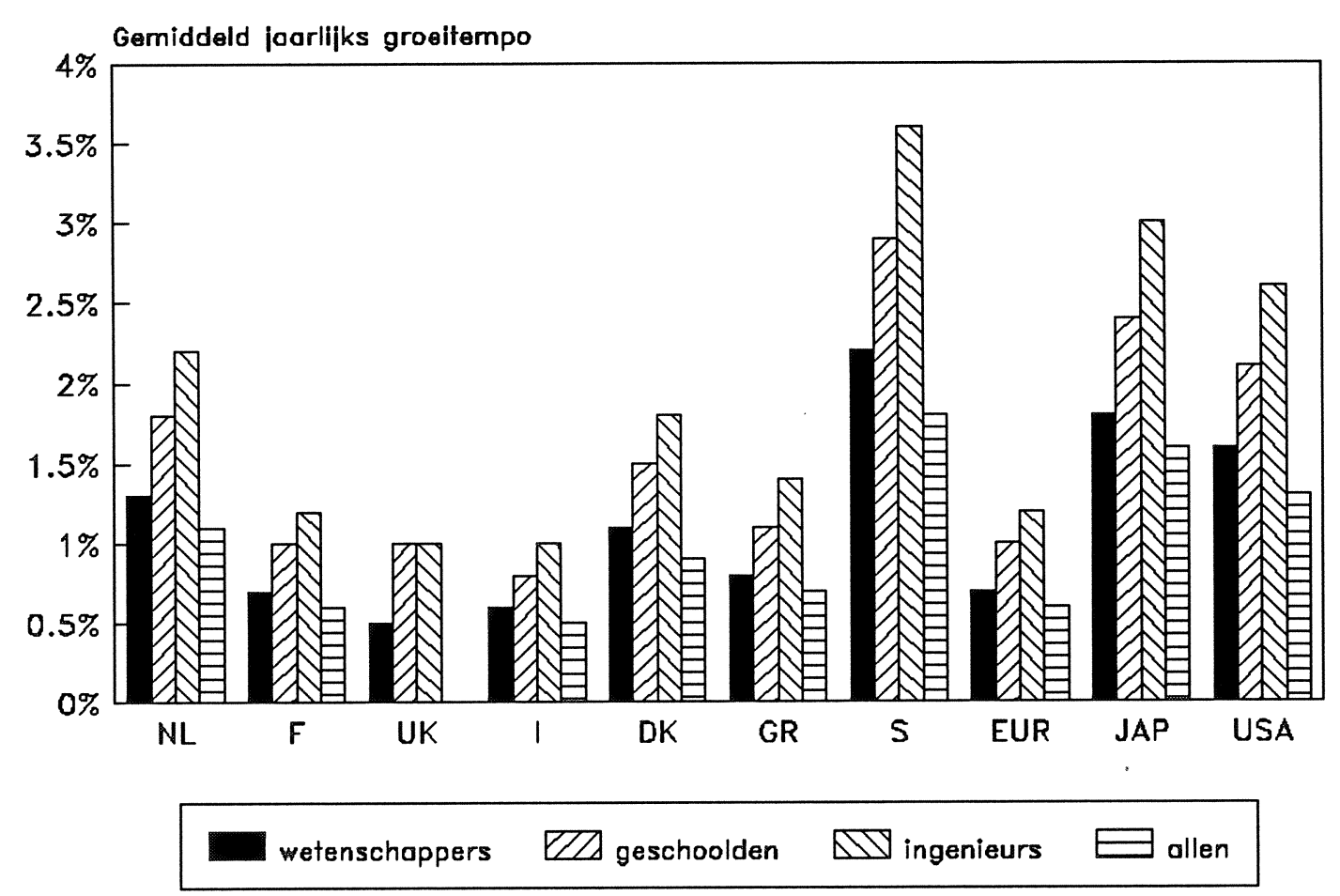

Bron : MERIT

Deze grafiek geeft een duidelijk beeld van de verwachte sterke vraag naar ingenieurs, die in Europa groeit met $1.2 \%$, tegenover een groei van de totale vraag met gemiddeld $0.6 \%$. Overigens moet opgemerkt worden dat de verwachte vraag in Europa, met uitzondering van Spanje, lager ligt dan in Japan of de Verenigde Staten. 


\subsubsection{Baanmobiliteit}

Door Van Ours (1990 en 1991) is een internationaal vergelijkend onderzoek gedaan naar de baanmobiliteit.

Van Ours vergelijkt voor een zestal landen de arbeidsmobiliteit en tracht de waargenomen verschillen te verklaren. In tabel 18 worden zijn resultaten met betrekking tot de mobiliteit van baan naar baan beknopt weergegeven.

Tabel 18. Omvang baan-baanmobiliteit bij een krappe arbeidsmarkt (in \% van het aantal werknemers)*

Inputdata

Mobiliteit

van baan

naar baan
Arbeidskrachtentelling periode
Bedrijfsenquête

periode

\begin{tabular}{lccc}
\hline Nederland & 8 & $75-85$ & -- \\
Verenigd Koninkrijk & 14 & $71-87$ & $70-88$ \\
Frankrijk & 15 & $77-88$ & -- \\
Zweden & 12 & $72-86$ & $75-86$ \\
Japan & 5 & $71-87$ & $71-87$ \\
\end{tabular}

*Veronderstellingen: werkloosheid $=2 \%$; werkgelegenheidsgroei $=1 \%$ per jaar

$--=$ niet beschikbaar

Bron: Van Ours (1991), blz. 16.

In tabel $18 \mathrm{komt}$ naar voren dat zich tussen de beschouwde landen grote verschillen voordoen ten aanzien van de mobiliteit van baan naar baan. Deze is het kleinst in Japan. In het Verenigd Koninkrijk, Frankrijk en Zweden is deze echter beduidend groter dan in Nederland. Volgens van Ours is het moeilijk aan te geven wat de belangrijkste reden is waarom de mobiliteit van baan naar baan in Nederland zo laag is in vergelijking met andere landen, met uitzondering van Japan. 'Wellicht is de geringe baanmobiliteit in Nederland niets anders dan een karakteristiek van de Nederlandse arbeidsmarkt, waarop aan een lange termijn-relatie tussen werkgever en werknemers een grote waarde wordt toegekend en aan een veelvuldig van baan veranderen niet. Wellicht speelt ook het sterke beroepsgerichte karakter van een belangrijk deel van het 
$-30-$

Nederlandse onderwijssysteem, waardoor het niet gemakkelijk is een eenmaal gekozen beroep te verruilen voor een ander, een rol $^{\prime}$.

Van Ours (1991, blz. 17) concludeert verder dat er aan de betekenis van de baanmobiliteit voor het functioneren van de arbeidsmarkt en meer in het bijzonder voor de werkloosheidsontwikkeling slechts beperkte waarde moet worden toegekend.

6. Van Ours, 1991, p. 16. 


\section{ONDERWIJS EN SCHOLING IN ZWEDEN}

\subsection{Inleiding}

In 1988 hebben medewerkers van de Directie Algemeen Technologiebeleid (ATB) een werkbezoek gebracht aan de Bondsrepubliek Duitsland. In 1990 werd een dergelijk bezoek aan het Verenigd Koninkrijk gebracht. De werkbezoeken vormden een onderdeel van een internationaal beleidsvergelijkend onderzoek op het gebied van onderwijs en scholing. De bevindingen werden vastgelegd in twee rapporten (Ministerie van Economische Zaken, 1988, 1990). In dit hoofdstuk wordt getracht middels een literatuurstudie, soortgelijke informatie te verstrekken voor Zweden, als in de genoemde rapporten voor de Bondsrepubliek Duitsland en het Verenigd Koninkrijk wordt weergegeven. Daarbij wordt waar mogelijk ook gekeken naar overeenkomsten en verschillen tussen de Bondsrepubliek Duitsland, het Verenigd Koninkrijk, Zweden en Nederland.

De probleemstelling die centraal staat in dit hoofdstuk is identiek aan de probleemstelling van de rapportages van de beide werkbezoeken. Het betreft twee vragen:

1. Wat is in de verschillende landen de betrokkenheid van het Ministerie van Economische zaken bij de beleidsvorming op het gebied van onderwijs en scholing?

2. Welke instellingen zijn er daarnaast betrokken bij het beleid op het terrein van scholing van werkenden?

Ook de opbouw van het hoofdstuk komt overeen met de opbouw van genoemde rapporten. Allereerst zal worden ingegaan op de Zweedse economie en de Zweedse arbeidsmarkt. Vervolgens wordt aandacht besteed op het onderwijssysteem en de scholingsactiviteiten in Zweden. Daarna wordt besproken welke partijen in dit land betrokken zijn bij onderwijs en scholing. Ten slotte worden enkele conclusies getrokken.

\subsection{Economie en arbeidsmarkt}

Zweden kan net als Nederland, zij het in iets mindere mate, gekarakteriseerd worden als een kleine open economie (De Neubourg, 1990). Het Bruto Nationaal Produkt per capita ligt voor zowel Zweden als Nederland internationaal gesproken op een hoog niveau. Zweden bevindt zich wat dit betreft, samen met de andere Scandinavische landen, Japan, Duitsland en Zwitserland aan de top van de OECD rangschikking. Tabel 19 geeft daar een indruk van. 
Tabel 19. Groei van het reëele Bruto Nationaal Produkt (\% mutatie t.o.v. vorige jaar)

\begin{tabular}{lrrrrrr}
\hline & 1987 & 1988 & 1989 & 1990 & 1991 & 1992 \\
\hline & & & & & & \\
Zweden & 2.6 & 2.3 & 2.1 & 0.3 & -0.9 & 0.4 \\
Nederland & 1.1 & 2.7 & 4 & 3.5 & 2.1 & 2.3 \\
BRD & 1.7 & 3.7 & 3.8 & 4.5 & 2.8 & 2.2 \\
Verenigd Koninkrijk & 4.7 & 4.2 & 1.9 & 0.6 & -1.8 & 1.6 \\
OECD totaal & 3.5 & 6.1 & 4 & 2 & 0.1 & 3.7 \\
& & & & & & \\
\hline
\end{tabular}

Bron: OECD (1991)

Tot 1985 was er in Zweden sprake van een fors budgettair tekort. Dit tekort was ontstaan onder invloed van de pogingen in de zeventiger jaren van de overheid om door middel van interventies het economisch tij te keren. Hierbij moet worden gedacht aan de werkgelegenheidscreatie in de publieke sector en de steun aan noodlijdende bedrijven. De werkloosheid bleef daardoor laag. In 1982 werd het beleid gewijzigd om het groeiende financieringstekort terug te dringen. Subsidies aan noodlijdende bedrijven werden afgeschaft, er werd bezuinigd op overheidsuitgaven en er vond een devaluatie plaats. Het streven naar volledige werkgelegenheid bleef echter deel uitmaken van het gevoerde beleid. De resultaten van het beleid waren in eerste instantie spectaculair. De groei van het BNP werd in de periode 1982-1987 hersteld en de investeringen gingen omhoog. Bovendien daalde zowel de werkloosheid als de inflatie. Echter, zoals uit tabel 19 blijkt, ligt de groei van het BNP in Zweden de laatste jaren onder het OECDgemiddelde.

In vergelijking met een aantal andere OECD-landen heeft Zweden de laagste werkloosheid. Tabel 20 laat echter zien dat de werkloosheid in Zweden thans stijgt in tegenstelling tot de totale OECD. Het feit dat de Zweedse overheid het stimuleringsbeleid heeft losgelaten, zal hier wellicht niet vreemd aan zijn.

Tabel 20. Ontwikkeling van het werkloosheidspercentage, 1987-1992

\begin{tabular}{lrrrrrl}
\hline & 1987 & 1988 & 1989 & 1990 & 1991 & 1992 \\
\hline Zweden & 1.9 & 1.6 & 1.4 & 1.5 & 2.8 & 3.6 \\
Nederland & 8.7 & 8.3 & 7.4 & 6.5 & 6.5 & 6.4 \\
BRD & 7.9 & 6.2 & 5.6 & 5.1 & 5 & 5.1 \\
Verenigd Koninkrijk & 10.4 & 8.2 & 6.2 & 5.5 & 8.2 & 9.6 \\
OECD totaal & 7.6 & 6.9 & 6.4 & 6.2 & 7.1 & 7.1 \\
\hline
\end{tabular}

Bron: OECD (1991) 
Opgemerkt moet worden dat de jeugdwerkloosheid doorgaans ongeveer $2 \%$ hoger ligt dan bovenstaande percentages (Ministry of Labour, Hultgren, 1990).

Behalve de werkloosheid is ook de hogere arbeidsmarktparticipatie van gehuwde vrouwen in Zweden opvallend. Dit verklaart in belangrijke mate waarom de algehele participatiegraad in Zweden een stuk hoger ligt dan in Nederland (De Neubourg, 1990). In Nederland nam in 1982'' 83 ongeveer $50 \%$ van de vrouwen in de leeftijdscategorie $25-54$ jaar niet deel aan het arbeidsproces, in Zweden bedroeg dit percentage slechts 12 .

\subsection{Onderwijssysteem}

Opvallend in Zweden zijn de relatief hoge collectieve uitgaven aan het onderwijssysteem. De uitgaven van de overheid in Zweden aan onderwijs bedragen per hoofd van de bevolking meer dan twee keer zoveel dan de gemiddelde uitgaven van de landen die deel uitmaken van de EG. Bovendien zijn deze uitgaven in de tachtiger jaren relatief, ten opzichte van de EG-landen, gestegen. Tabel 21 geeft een beeld van de onderwijsuitgaven in Zweden.

Tabel 21. Uitgaven aan onderwijs per hoofd van de bevolking tussen 5 en 24 jaar in Zweden (vergeleken met het EG-gemiddelde $=100$ )

Jaar

Bron: Ministry of Labour, Hultgren (1990)

Deze hoge uitgaven zijn ten dele terug te voeren op het feit dat het gehele onderwijssysteem, uitzonderingen daargelaten, gratis is.

Wat de structuur van het Zweedse onderwijssysteem betreft kan worden opgemerkt dat het op een aantal punten afwijkt van het Nederlandse systeem. Na de kleuterschool volgen de kinderen gedurende 9 jaar een lagere school (opgesplitst in 3 achtereenvolgende fasen). Vanaf het vierde leerjaar krijgen de kinderen ook les in engels en exacte vakken. Vanaf het zevende jaar worden meer vreemde talen gedoceerd en worden engels en wiskunde op verschillende niveaus gegeven. Tevens zijn er in de derde fase werkervaringsprogramma's van 6 tot 10 weken. Deze programma's bevatten werkbezoeken aan en gesimuleerde werksituaties in bedrijven in de 
directe omgeving van de school (Ministerie van Werkgelegenheid, Hultgren, 1990).

$\mathrm{Na}$ de lagere school gaan bijna alle kinderen naar het zogenaamde "geïntegreerde Gymnasium". De opleiding, ingevoerd bij de onderwijshervorming in 1971, integreert het (theoretische) Gymnasium met de beroepsopleiding en het leerlingwezen. Deze opleiding betreft een dertigtal richtingen verdeeld over een zestal sectoren. De tweejarige opleiding, die toegang geeft tot de universiteit, bevat zowel theoretische vakken als beroepskwalificerende vakken (onder andere op een werkplek). Opvallend is het feit dat juist de theoriecomponent van de opleiding door werkgevers wordt bekritiseerd. Op dit moment worden er voorstellen besproken om de opleiding met éen jaar te verlengen om zodoende zowel meer aandacht aan theoretische scholing, als aan 'on the job training' te kunnen besteden.

Het leerlingwezen, buiten het geïntegreerde Gymnasium, bestaat in Zweden slechts voor een paar sectoren en is van te verwaarlozen omvang ( $1 \%$ van de beroepsopleidingen). Het lijkt erop dat het geïntegreerd Gymnasium voldoende mogelijkheden biedt voor het opdoen van beroepsmatige werkervaring. Het is derhalve onjuist te constateren dat Zweden, in vergelijking met Nederland, Engeland en Duitsland een gering aantal leerlingen in het duale stelsel heeft. Het gehele onderwijssysteem heeft een sterke beroepsmatige; praktische en op de arbeidsmarkt gerichte inslag. Qua praktijkgerichtheid hoeft het Zweedse geïntegreerde Gymnasium niet onder te doen voor het duale systeem in Duitsland.

Evenals bij het Nederlandse onderwijssysteem het geval is, kunnen leerlingen na het geïntegreerde Gymnasium doorstromen naar een universiteit of hogeschool. Ongeveer $20 \%$ van de leerlingen stroomt door naar deze opleidingen.

Van Dam en De Grip (1990) hebben reeds geconstateerd dat het aandeel van het beroepsonderwijs in het totale reguliere onderwijs zowel in Zweden als in Nederland hoog is, respectievelijk $50 \%$ en $57 \%$.

\subsection{Scholing}

Naast het initiële onderwijs zijn er vormen van volwasseneneducatie en 'on the job training'. In Zweden wordt intensief geschoold. Het betreft zowel scholing van werkenden als van werklozen. In tabel 22 wordt voor een aantal landen een aantal indicatoren hiervoor weergegeven. De data hebben betrekking op verschillende jaren. 
Tabel 22. Indicatoren voor (beroepsgerichte) volwasseneneducatie en scholing door bedrijven

\begin{tabular}{lcccc}
\hline Land & Zweden & Nederland & West-Duitsland $\begin{array}{c}\text { Verenigd } \\
\text { Koninkrijk } \\
1984 \%\end{array}$ \\
Jaar & $1987 \%$ & $1986 \%$ & $1985 \%$ & \\
\hline $\begin{array}{l}\text { Deelnemers beroepsgerichte } \\
\text { volw. educatie / beroepsbevolking }\end{array}$ & 66 & 20 & 23 & \\
$\begin{array}{l}\text { Jaarlijkse cursisten/werkenden } \\
\text { Uitgaven (beroepsger.) volw. }\end{array}$ & 34 & 37 & 10 & \\
educatie / BNP & 3.0 & 0.95 & 0.92 & 1.13 \\
waarvan: bedrijven & 1.98 & 0.71 & 0.81 & 0.67 \\
overheid & 1.02 & 0.18 & 0.11 & 0.42 \\
$\begin{array}{l}\text { Scholing bedrijven/loonsom } \\
\text { Scholing bedrijven/bruto }\end{array}$ & 5.0 & 1.4 & 1.5 & 1.2 \\
investeringen (excl. woningbouw) & 20.2 & 6.3 & 6.5 & 8.4 \\
\hline & & & & \\
\hline
\end{tabular}

Bron: Boot (1989)

Toelichting: / betekent 'uitgedrukt als \% van'.

Uit de tabel blijkt dat Zweden op alle dimensies het hoogste scoort. Wel moet daarbij in aanmerking worden genomen dat de data voor Zweden het meest recent zijn.

De Zweedse overheid heeft op het terrein van de beroepsscholing zeer stimulerend opgetreden. In 1986 werden alle bedrijven, behalve de zeer kleine, verplicht om eenmalig 10\% van de winst over 1985 op een speciale 'Innovatierekening' te zetten. Tot 1991 mag dat geld besteed worden aan de financiering van scholingsonderzoeks- en ontwikkelingsactiviteiten (O\&O), mits er met de vakbond overeenstemming is over de besteding ervan in concrete projecten. In 1988 werd de besteding van deze fondsen voor het eerst geëvalueerd. Van het geld op de Innovatierekeningen, ongeveer 1,6 miljard gulden, was $40 \%$ goedgekeurd aan projecten. Van deze projecten had $78 \%$ betrekking op scholing (de rest op O\&O). Van het toegewezen geld was uiteindelijk $41 \%$ aan scholing besteed en de rest aan $0 \& 0$. De meeste scholing had betrekking op beroepsspecifieke bij- en herscholing. Hoewel de vakbeweging zich ook had ingespannen voor projecten speciaal gericht op ongeschoolden en vrouwen, was niet helemaal duidelijk of deze projecten al daadwerkelijk van de grond waren gekomen (Boot, 1989).

Momenteel wordt overwogen om de scholing nog verder te intensiveren. De vakbeweging heeft daartoe vergaande voorstellen gedaan. Elke werknemer zou een individueel scholingsrecht van twee weken moeten krijgen, terwijl werkenden die niet een beroepsopleiding hebben afgerond een scholingsrecht van nog eens eenmalig 175 scholingsdagen zouden moeten krijgen (Boot, 1989). 
Met betrekking tot de scholing van werklozen kan worden opgemerkt dat scholing een belangrijke pijler is van het gevoerde arbeidsvoorzieningenbeleid. Gedurende de periode 1975 - 1985 nam een kwart deel van alle werklozen gedurende enige tijd deel aan een vorm van scholing. De scholing vindt met name plaats in opleidingscentra van de arbeidsvoorziening. De scholingsactiviteiten in deze centra duren ongeveer vier maanden. De deelnemers krijgen een beloning ter hoogte van hun uitkering. Tweederde van de deelnemers van dit type scholing blijkt binnen zes maanden een baan te hebben (Van Altena e.a., 1990, Wouters, 1988).

De zogenaamde AMU-groep organiseert scholing in naam van de Raad voor de Arbeidsmarkt. De AMU-groep is de grootste organisator van beroepsscholing voor volwassenen in Zweden.

Voor de negentiger jaren is het scholingsbeleid vooral gericht op "upskilling" van de beroepsbevolking (Ministry of Labour, 1988). Daartoe wordt het scholingsbeleid in een breder kader geplaatst van een zogeheten "working life policy" in het kader waarvan onder andere ook de arbeidsomstandigheden en de medezeggenschap worden geregeld. Ook educatief verlof, sinds 1982 wettelijk vastgelegd, speelt hierbij een belangrijke rol (Ministry of Labour, 1985). Hoewel werkgevers zelf een belangrijke verantwoordelijkheid dragen voor het succesvol uitvoeren van het scholingsbeleid kent de overheid zichzelf in de negentiger jaren een belangrijke rol toe, ook als het gaat om "in house" scholingsactiviteiten. Als belangrijkste argument hiervoor wordt genoemd de noodzaak te voorkomen dat slechts die werknemers profiteren, die toch al over een goede (basis)opleiding beschikken. Speciale aandacht dient daarbij volgens het Ministerie van Arbeid te worden besteed aan de al wat oudere werknemers en vrouwen (Van Altena e.a., 1990).

\subsection{Betrokken partijen bij arbeidsmarkt- en scholingsbeleid}

De voorbereiding en uitvoering van het onderwijs- en arbeidsmarktbeleid wordt op landelijk niveau gevoerd door het Ministerie van Onderwijs, het Ministerie van Arbeid, de Nationale Raad voor Onderwijs, de Nationale Raad voor de Universiteiten, de Nationale Raad voor de Arbeidsmarkt en de AMU-groep (Ministry of Labour, Hultgren, 1990; Brouwer, 1990). De vakbonden en de werkgevers zijn bij de besluitvorming betrokken en de Nationale Raad voor Onderwijs, de Nationale Raad voor de Universiteiten, de Nationale Raad voor de Arbeidsmarkt en de AMUgroep hebben daarbij een adviserende rol.

De nationale Raad voor Onderwijs doet voorstellen met betrekking tot het lagere onderwijs en het Geïntegreerde Gymnasium. Daarbij wordt samengewerkt met vakbonden en werkgevers. Het universitair onderwijs is op soortgelijke wijze georganiseerd. De Raad voor Universiteiten, 
vakbonden en werkgevers doen voorstellen. De uiteindelijke beslissingen worden door regering en parlement genomen.

Verder zijn er met betrekking tot het beroepsonderwijs landelijke, regionale en lokale adviesorganen, waarin werkgevers en werknemers vertegenwoordigd zijn. Deze adviesorganen hebben als doel een betere samenwerking tussen werkgevers en werknemers tot stand te brengen met betrekking tot de organisatie van trainingen voor werkenden.

Brouwer constateert dat in Zweden werkgevers en vakbonden daadwerkelijk onderling samenwerken, terwijl in Nederland er meer sprake is van een onderhandelingssituatie.

In figuur 5 is een schema opgenomen dat inzicht geeft in de invloed van diverse organen in het onderwijs.

\subsection{Conclusies}

Nederland en Zweden verschillen met betrekking tot de omvang van de werkloosheid, de participatiegraad van vrouwen en de economische ontwikkeling.

Het onderwijssysteem kent een sterke beroepsmatige en praktische gerichtheid op de arbeidsmarkt. Vanaf de lager school worden werkervaringsprogramma's georganiseerd. Ook scholing staat in Zweden op een hoog peil. Wat de scholingsinspanningen betreft, loopt Zweden, in vergelijking met andere landen, op kop.

Het onderwijs- en scholingsbeleid wordt georganiseerd door het Ministerie van Onderwijs en het Ministerie van Arbeid en tal van raden. Er is een tripartite structuur zowel met betrekking tot het onderwijs- als het arbeidsmarktbeleid. Vakbonden en werkgevers werken goed met elkaar samen. 
Figuur 5. Invloed van actoren op het onderwijs in Zweden

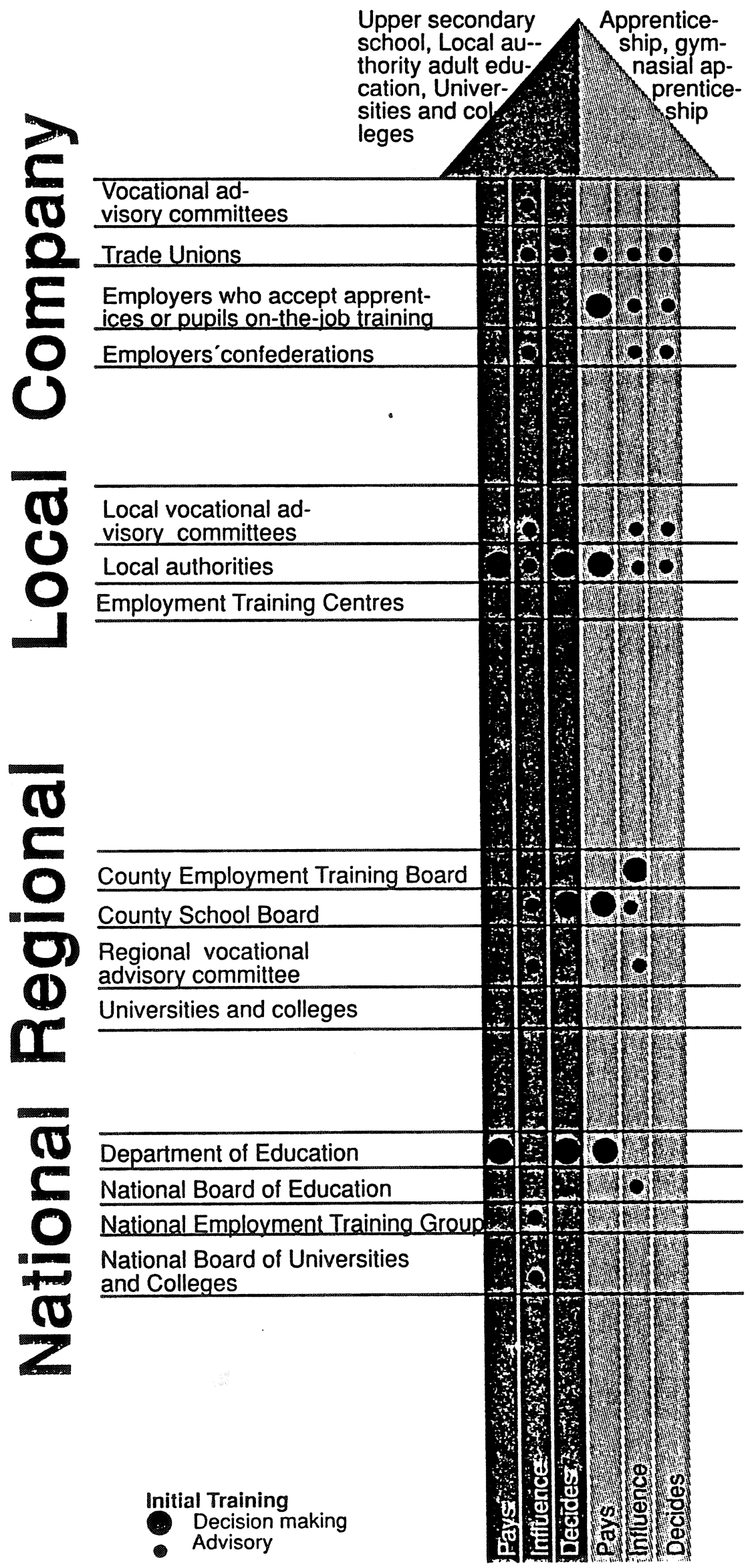

Bron: Ministry of Labour, Hultgren 


\section{VROUWEN IN TECHNISCHE OPLEIDINGEN EN BEROEPEN}

\subsection{Inleiding}

Sinds 1981 streeft de regering er naar om zogenaamde 'mannenberoepen' toegankelijker te maken voor vrouwen (Brouns en Schokker, 1990). Vrouwen worden bijvoorbeeld gestimuleerd technische beroepen uit te gaan oefenen. Tevens voert de regering publiciteitscampagnes om te bevorderen dat meisjes op de middelbare school exacte vakken in het pakket opnemen. Deze campagnes worden door het bedrijfsleven ondersteund. Daarbij komt dat het steeds moeilijker blijkt te zijn om vacatures, waarvoor een lagere technische opleiding is vereist, op te vullen. Behalve de emancipatiemotieven spelen hier vooral ook allocatiemotieven op de arbeidsmarkt een rol. Het onbenut laten van een deel van het arbeidspotentieel kan immers worden beschouwd als een vorm van inefficiënte allocatie.

In dit hoofdstuk zal een aantal gegevens worden gepresenteerd die een beeld geven van de mate waarin vrouwen participeren in technische opleidingen en beroepen in Nederland en waar mogelijk in een aantal andere OECD-landen. Ter vergelijking worden cijfers over mannen bijgevoegd.

De opbouw van dit hoofdstuk correspondeert met de onderwijs- en beroepscarrière van individuen. Op de middelbare school (§ 5.2) worden al dan niet exacte vakken in het pakket opgenomen. $\mathrm{Na}$ het verlaten van de middelbare school (al dan niet met diploma) kan worden gekozen voor een (technische) vervolgopleiding ( $\$ 5.3$ ). Deze opleiding wordt al dan niet met succes afgerond ( $\S 5.4$ ). Daarna wordt geparticipeerd op de arbeidsmarkt ( $\$ 5.5$ ), al dan niet in een technisch beroep. In de laatste paragraaf wordt een aantal conclusies getrokken.

\subsection{Exacte vakken op de middelbare school}

Teneinde een indruk te krijgen van de mate waarin technische vervolgopleidingen en beroepen toegankelijk zijn voor vrouwen, is het zinvol een beeld te hebben van het aantal en de soort exacte vakken die meisjes in het voortgezet onderwijs kiezen. In tabel 23 worden de cijfers met betrekking tot het aantal exacte vakken gepresenteerd voor het MAVO, HAVO en VWO. 
Tabel 23. Aantal exacte vakken in het eindexamenpakket op de middelbare school naar geslacht*

\begin{tabular}{|c|c|c|c|c|c|c|c|c|c|}
\hline \multirow[t]{2}{*}{ Schoolsoort } & \multirow{2}{*}{$\begin{array}{l}\text { aantal exacte } \\
\text { vakken }\end{array}$} & \multicolumn{2}{|r|}{1980} & \multicolumn{2}{|c|}{1985} & \multicolumn{2}{|c|}{1988} & \multicolumn{2}{|c|}{1989} \\
\hline & & v & M & V & $M$ & V & $M$ & V & $M$ \\
\hline \multirow[t]{4}{*}{ MAVO } & 0 & 22 & (11) & 18 & (7) & 35 & $(11)$ & 31 & (10) \\
\hline & 1 & 39 & (19) & 34 & (17) & 36 & (23) & 37 & (20) \\
\hline & 2 & 19 & $(18)$ & 25 & (26) & 19 & (29) & 22 & (31) \\
\hline & 3 of meer & 20 & (51) & 20 & (47) & 10 & (37) & 10 & (38) \\
\hline \multirow[t]{3}{*}{ HAVO } & 0 & 43 & (25) & 30 & (16) & 50 & (20) & 44 & (17) \\
\hline & 1 & 29 & (18) & 30 & $(21)$ & 29 & $(26)$ & 34 & (26) \\
\hline & 2 of meer & 19 & (34) & 26 & $(37)$ & 12 & $(22)$ & 12 & (24) \\
\hline \multirow[t]{5}{*}{ vwo } & 0 & 35 & $(16)$ & 28 & $(12)$ & 24 & (7) & 22 & (6) \\
\hline & 1 & 23 & (14) & 26 & $(16)$ & 38 & $(22)$ & 41 & (24) \\
\hline & 2 & 7 & (5) & 11 & $(10)$ & 1 & $(14)$ & 14 & (15) \\
\hline & 3 & 14 & $(15)$ & 15 & $(21)$ & 20 & $(36)$ & 18 & (36) \\
\hline & 4 of meer & 24 & (46) & 19 & $(41)$ & 5 & $(20)$ & 5 & (17) \\
\hline
\end{tabular}

\footnotetext{
* $\mathrm{V}=\%$ bij vrouwen

$M=\%$ bij mannen

Bron: ROA/CBS
}

Bij het MAVO is duidelijk dat jongens meer exact kiezen dan meisjes. Jongens nemen vaker drie of vier exacte vakken, meisjes vaker geen of slechts één exact vak. In de loop van de tachtiger jaren is bovendien het aantal meisjes dat geen exact vak kiest toegenomen. In 1980 en 1985 kiest ongeveer $20 \%$ van de meisjes geen enkel exact vak. In de tweede helft van de jaren '80 loopt dit percentage op tot ruim $30 \%$.

In het HAVO is de keuze van het aantal exacte vakken in de jaren tachtig redelijk constant, afgezien van het jaar 1985. Ook bij het HAVO zien we dat jongens aanzienlijk vaker exacte vakken kiezen dan meisjes.

Bij het VWO hebben sinds 1985 meisjes meer exacte vakken in hun pakket opgenomen, alhoewel het percentage dat vier of meer exacte vakken kiest is gedaald. Bij jongens is dezelfde ontwikkeling te zien. Ook voor het VWO geldt dat meisjes beduidend minder exacte vakken kiezen dan jongens. 
Tabel 24. Soort exacte vakken in het eindexamenpakket op de middelbare school naar geslacht*

\begin{tabular}{|c|c|c|c|c|c|}
\hline \multirow[t]{2}{*}{ Schoolsoort } & \multirow[t]{2}{*}{ soort exacte vakken } & 1980 & 1985 & 1988 & 1989 \\
\hline & & V M & V M & V $M$ & V M \\
\hline \multirow[t]{4}{*}{ MAVO } & Wiskunde & $30(67)$ & $46(79)$ & $54(84)$ & $59(84)$ \\
\hline & Natuurkunde & $11(50)$ & $13(58)$ & $15(57)$ & $16(60)$ \\
\hline & Scheikunde & $37(52)$ & $37(57)$ & $36(54)$ & $36(55)$ \\
\hline & Biologie & $72(47)$ & $61(36)$ & $57(32)$ & 56 (29) \\
\hline \multirow[t]{4}{*}{ HAVO } & Wiskunde & $32(63)$ & $42(73)$ & $44(77)$ & $51(80)$ \\
\hline & Natuurkunde & $11(43)$ & $14(51)$ & $13(51)$ & $12(51)$ \\
\hline & Scheikunde & $28(44)$ & $32(46)$ & 24 (39) & $24(40)$ \\
\hline & Biologie & $57(45)$ & $54(39)$ & $43(27)$ & $41(25)$ \\
\hline \multirow[t]{7}{*}{ vwo } & Wiskunde I & $53(79)$ & $59(82)$ & & \\
\hline & Wiskunde II & $4(25)$ & $6(27)$ & & \\
\hline & Wiskunde A & & & $55(61)$ & $58(61)$ \\
\hline & Wiskunde B & & & $29(63)$ & $31(62)$ \\
\hline & Natuurkunde & $26(61)$ & $28(64)$ & 27 (63) & $31(62)$ \\
\hline & Scheikunde & $32(58)$ & $35(56)$ & $30(52)$ & $29(48)$ \\
\hline & Biologie & $46(47)$ & $48(41)$ & $39(33)$ & $39(31)$ \\
\hline
\end{tabular}

* $\mathrm{V}=\%$ bij vrouwen

$M=\%$ bij mannen

Bron: ROA/CBS

Met betrekking tot het soort exacte vakken dat wordt gekozen op het MAVO, valt op dat wiskunde steeds meer en biologie steeds minder wordt gekozen (zowel door jongens als door meisjes). Het verschil tussen het percentage jongens en het percentage meisjes is bij vrijwel ieder exact vak erg groot. Met uitzondering van het vak biologie zijn de exacte vakken aanzienlijk populairder bij jongens dan bij meisjes.

Ook bij het HAVO wordt zowel door jongens als meisjes wiskunde in toenemende mate gekozen. Voor biologie geldt dezelfde conclusie als bij het MAVO. Ook scheikunde wordt de laatste jaren minder vaak gekozen dan in 1985.

De toename van het aantal meisjes dat het vak natuurkunde in het vakkenpakket opneemt is minimaal; bij scheikunde is er sprake van een lichte daling. Bij het VWO moet de sterke toename van de keuze van wiskunde $B$ (zowel door jongens als door meisjes) worden toegeschreven aan de verandering van het wiskunde onderwijs. Het vak wiskunde $A$ is eenvoudiger dan het vak wiskunde I, dat in het begin van de jaren ' 80 gegeven werd. 
Met betrekking tot alle middelbare schooltypes tezamen kunnen een paar algemene conclusies getrokken worden:

- jongens kiezen duidelijk meer exacte vakken dan meisjes; deze conclusie wordt ondersteund door het Schoolverlatersonderzoek van het NIPO (1989);

- sinds 1985 is het percentage meisjes dat éen of meer exacte vakken kiest bij het MAVO gedaald, bij het HAVO constant gebleven en bij het VWO gestegen;

- wiskunde wordt in toenemende mate gekozen, biologie in mindere mate;

- op het HAVO is het percentage leerlingen dat én of meer exacte vakken kiest lager dan op het MAVO en het VWO.

Een internationale vergelijking is niet mogelijk vanwege de te grote verschillen in opleidingsstructuur tussen de verschillende landen.

Ten einde meisjes te stimuleren om exacte vakken te kiezen, is het niet alleen nodig om het feitelijke keuzegedrag van meisjes te kennen, maar is het bovendien nodig om te weten welke factoren aan dit gedrag ten grondslag liggen en in hoeverre het keuzegedrag te beïnvloeden is door gericht beleid. Een evaluatie van de campagne 'Kies Exact' leverde een aantal inzichten op:

- De campagne heeft een positief effect gehad op de houding van meisjes bij het kiezen van exacte vakken. Het percentage meisjes dat zich voorneemt om exacte vakken op te nemen is daardoor gestegen.

- Het percentage meisjes dat in het examenpakket exacte vakken heeft opgenomen is door de campagne niet gestegen. Uit het Schoolverlatersonderzoek (NIPO, 1989) blijkt dat 30\% van de vrouwelijke eindexamenkandidaten het aanvankelijk gekozen pakket alsnog heeft gewijzigd. Doorgaans worden dan exacte vakken door niet-exacte vakken vervangen.

- Van de meisjes die exacte vakken kiezen slagen er ongeveer evenveel voor het examen als jongens.

- Leerlingen, ouders en decanen/docenten verschillen van mening over de invloed die de sociale omgeving uitoefent op de pakketkeuze. Leerlingen vinden ouders en decanen de belangrijkste gesprekspartners bij de pakketkeuze. Ouders en docenten vinden dat leerlingen zelf de meeste invloed hebben op de pakketkeuze. Ouders vinden dat zij minder invloed hebben dan decanen. Decanen vinden dat zij minder invloed hebben dan ouders.

- De meeste decanen zeggen in hun voorlichting over studie- en beroepskeuze geen onderscheid te maken tussen jongens en meisjes; slechts een vijfde geeft speciale voorlichting aan meisjes om hen te interesseren voor exacte vakken. Decanen/docenten vinden dat ouders hun dochters te weinig stimuleren om exacte vakken te kiezen. Volgens hen is dit één van de redenen waarom meisjes zo weinig voor exacte vakken kiezen. Een andere veel genoemde reden is het gebrek aan voorbeelden van vrouwen die in een exact beroep werkzaam zijn.

- De sociale omgeving (ouders, decanen) van meisjes blijkt van invloed te zijn op voornemens, 
keuzes en resultaten van meisjes met betrekking tot exacte vakken.

Kuyper en Van der Werf (1991) onderzoeken de invloed van docenten op de sekseverschillen bij wiskunde. Op basis van hun onderzoek trekken zij de volgende conclusies:

- Docenten hebben andere verwachtingen van jongens dan van meisjes. Zij verwachten dat jongens vaker wiskunde in het pakket opnemen en denken dat jongens beter zouden kunnen presteren dan ze doen, terwijl meisjes aan hun top zouden zitten wat prestaties betreft. Tevens adviseren ze jongens vaker om wiskunde in het pakket op te nemen.

- Meisjes hebben een significant andere attitude ten aanzien van wiskunde dan jongens.

- Docenten hebben geen significante invloed op de verschillen tussen jongens en meisjes in de prestaties in wiskunde, de attitude ten opzichte van wiskunde en de keuze van wiskunde.

Geconcludeerd kan worden dat onderzoek naar de oorzaak van sekseverschillen met betrekking tot exacte vakken relevante aanknopingspunten biedt voor beleid. In de evaluatie van de campagne 'Kies Exact' komt naar voren dat het beleid zich meer zal moeten richten op de directe omgeving van meisjes: ouders, decanen en docenten.

\subsection{Keuze voor een technische vervolgopleiding}

In deze paragraaf wordt de keuze voor een technische vervolgopleiding besproken. De uitstroom naar een technische opleiding op lager, middelbaar en hoger niveau is berekend als percentage van de keuze voor een beroepsopleiding op gelijkwaardig niveau. Dit is gedaan voor een aantal vooropleidingen (MAVO, HAVO, VWO). Voor een technische toelichting op de in deze paragraaf gepresenteerde tabellen wordt verwezen naar bijlage III.

Uit tabel 25 blijkt dat bij jongens het percentage dat voor het Lager Technisch Onderwijs (LTO) of het Lager Nautisch Onderwijs (LNO) kiest aanzienlijk hoger ligt dan bij meisjes. Bij het basisen speciaal onderwijs is in afnemende mate sprake van leerlingen die voor het LTO of LNO kiezen. Dit geldt de laatste jaren met name voor meisjes. Voor de Brugklas geldt hetzelfde. De gediplomeerde meisjes van het MAVO kennen een tamelijk constante uitstroom naar het $L T O / L N O$. Bij de jongens is er sprake van een lichte daling. 
Tabel 25. Keuze voor het LTO/LNO als percentage van de keuze voor het LBO*

\begin{tabular}{llrrrr}
\hline & & $\begin{array}{c}1987 \\
\%\end{array}$ & $\begin{array}{c}1988 \\
\%\end{array}$ & $\begin{array}{c}1989 \\
\%\end{array}$ & $\begin{array}{c}1989 \\
\text { N }\end{array}$ \\
& & & & & \\
\hline \multirow{3}{*}{ BAO/SO } & vrouw & 4 & 3 & 3 & 564 \\
& man & 48 & 52 & 53 & 11110 \\
Brugklas & vrouw & 2 & 3 & 4 & 217 \\
& man & 48 & 52 & 53 & 3213 \\
MAVO2 & vrouw & 4 & 7 & 8 & 1777 \\
& man & 60 & 60 & 57 & 1630 \\
MAVO2M & vrouw & 62 & 58 & 83 & 221 \\
& man & 87 & 82 & & 501 \\
\hline
\end{tabular}

BAO = basisonderwijs $/$ SO $=$ speciaal onderwijs

MAVO2 = MAVO2 en hoger zonder diploma

MAVO2M = MAVO2 en hoger met diploma

Bron: ROA/CBS

Door een gewijzigde systematiek in de onderwijsmatrices van het CBS zijn de cijfers van vór 1987 niet goed vergelijkbaar met recentere gegevens.

Uit tabel 26 blijkt dat jongens vaker voor het MTO/MNO kiezen dan meisjes. De percentages zijn, met uitzondering van het basis- en speciaal onderwijs, redelijk constant in de tijd.

Tabel 26. Keuze voor het MTO/MNO als percentage van de keuze voor het MBO

\begin{tabular}{|c|c|c|c|c|c|c|c|c|}
\hline & & $\begin{array}{c}1980 \\
\%\end{array}$ & $\begin{array}{c}1985 \\
\%\end{array}$ & $\begin{array}{c}1986 \\
\%\end{array}$ & $\begin{array}{c}1987 \\
\%\end{array}$ & $\begin{array}{c}1988 \\
\%\end{array}$ & $\begin{array}{c}1989 \\
\%\end{array}$ & $\begin{array}{c}1989 \\
N\end{array}$ \\
\hline \multirow[t]{2}{*}{ so } & vrouw & 43 & 32 & 4 & 3 & 17 & 10 & 41 \\
\hline & man & 51 & 41 & 25 & 27 & 33 & 22 & 204 \\
\hline \multirow[t]{2}{*}{ MAVO2X } & vrouw & 5 & 5 & 5 & 5 & 6 & 8 & 1924 \\
\hline & man & 51 & 38 & 38 & 38 & 38 & 42 & 9549 \\
\hline VWO/ & vrouw & & 3 & 2 & 5 & 5 & 18 & 72 \\
\hline HAVO2 & $\operatorname{man}$ & & 51 & 55 & 47 & 48 & 55 & 317 \\
\hline \multirow[t]{2}{*}{ HAVO4X } & vrouw & 7 & 9 & 9 & 11 & 11 & 11 & 709 \\
\hline & man & 47 & 33 & 32 & 31 & 31 & 32 & 1908 \\
\hline \multirow[t]{2}{*}{ vw04X } & vrouw & 19 & 12 & 20 & 17 & 17 & 19 & 92 \\
\hline & $\operatorname{man}$ & 54 & 40 & 39 & 47 & 38 & 42 & 116 \\
\hline
\end{tabular}

SO $=$ speciaal onderwijs

MAVO2X = MAVO2 en hoger, zowel ongediplomeerden als gediplomeerden VWO/HAVO2 = VWO en HAVO, leerjaren 2 en 3

HAVO4X = HAVO 4 en hoger, zowel ongediplomeerden als gediplomeerden VWO4X = VWO4 en hoger, zowel ongediplomeerden als gediplomeerden

Bron: ROA/CBS 
In tabel 27 worden de cijfers voor het Hoger Technisch en Nautisch Onderwijs (HTNO) weergegeven. Evenals bij het MTO/MNO het geval is blijkt ook dat de percentages voor mannen beduidend hoger zijn dan voor de vrouwen. Bij het HAVO en het VWO zijn de percentages voor de vrouwen tamelijk constant (rond de $8 \%$ ). Van de mannen kiest ruim eenderde voor een technische richting.

Tabel 27. Keuze voor het HTNO als percentage van de keuze voor het HBO

\begin{tabular}{|c|c|c|c|c|c|c|c|c|}
\hline & & $\begin{array}{c}1980 \\
\%\end{array}$ & $\begin{array}{c}1985 \\
\%\end{array}$ & $\begin{array}{c}1986 \\
\%\end{array}$ & $\begin{array}{c}1987 \\
\%\end{array}$ & $\begin{array}{c}1988 \\
\%\end{array}$ & $\begin{array}{c}1989 \\
\%\end{array}$ & $\begin{array}{c}1989 \\
N\end{array}$ \\
\hline \multirow[t]{2}{*}{ HAVO4 } & vrouw & 8 & 8 & 7 & 8 & 8 & 8 & 666 \\
\hline & $\operatorname{man}$ & 34 & 39 & 37 & 38 & 38 & 39 & 2874 \\
\hline \multirow[t]{2}{*}{ VW04 } & vrouw & 8 & 8 & 8 & 8 & 10 & 10 & 446 \\
\hline & $\operatorname{man}$ & 38 & 37 & 36 & 36 & 37 & 34 & 1353 \\
\hline
\end{tabular}

HAVO4 = HAVO4 en hoger

VWO4 = VWO4 en hoger

Bron: ROA/CBS

Voor het wetenschappelijk onderwijs is het niet mogelijk om een soortgelijke tabel te construeren. De onderwijsmatrix geeft geen informatie over technische opleidingen op wetenschappelijk niveau. Wel kan op basis van de raming voor het WO (WORSA) een indruk worden gegeven van het aandeel van vrouwen in de eerstejaarsstudenten van technische richtingen. Tabel 28 geeft daar inzicht in.

Uit de tabel blijkt dat er sprake is van een gestage groei van het aandeel van vrouwen in technische studies. Bij natuurwetenschappen is het aandeel van vrouwen constant.

Alleen met betrekking tot technische opleidingen op wetenschappelijk niveau zijn data voorhanden van andere OECD-landen. Deze staan vermeld in tabel 29. Onder technische studierichtingen wordt in deze tabel begrepen: natuurwetenschappen, wiskunde, informatica, engineering en bouwkunde.

Uit de tabel blijkt dat Nederland relatief laag scoort met betrekking tot het aandeel van vrouwen in technische studierichtingen. Alleen Zwitserland en Japan scoren nog lager. 
Tabel 28. Aandeel van vrouwen in de eerstejaarsstudenten van technische en natuurwetenschappelijke studierichtingen in het WO $(\%)$

\begin{tabular}{|c|c|c|}
\hline Jaar & $\begin{array}{l}\text { Technische richtingen " } \\
\%\end{array}$ & $\begin{array}{l}\text { Natuurwetenschappen "* } \\
\%\end{array}$ \\
\hline '85/'86 & 10.8 & 20.3 \\
\hline '86/'87 & 11.0 & 22.6 \\
\hline ' $87 /{ }^{\prime} 88$ & 13.4 & 22.6 \\
\hline '88/'89 & 13.8 & 22.4 \\
\hline '89/'90 & 15.0 & 22.3 \\
\hline '90/'91 & 15.5 & 22.9 \\
\hline '91/'92 & 15.7 & 23.1 \\
\hline '96/97 & 15.8 & 23.1 \\
\hline $2001 /{ }^{\prime} 02$ & 15.7 & 23.1 \\
\hline
\end{tabular}

Bron: Taakgroep Studentenraming, WORSA 1990

Onder technische studierichtingen wordt verstaan: civiele techniek, bouwkunde, werktuigbouwkunde, elektrotechniek, scheikundige technologie, technische natuurkunde, lucht \& ruimtevaart, industrieel ontwerpen, scheepsbouwkunde, geodesie, mijnbouwkunde, metaalkunde en techniek \& maatschappij.

* * Onder natuurwetenschappen wordt verstaan: wis-, schei-, natuur- en sterrenkunde, informatica, farmacie, biologie, geologie, geofysica.

Tabel 29. Aandeel van vrouwen in technische studierichtingen op wetenschappelijk niveau (\%)

\begin{tabular}{lcc}
\hline & $\begin{array}{c}1980 \\
\%\end{array}$ & $\begin{array}{c}1987 \\
\%\end{array}$ \\
\hline Nederland & 11.2 & 15.1 \\
België & 24.8 & 26.5 \\
Verenigd Koninkrijk & 16.6 & 20.9 \\
West-Duitsland & 17.6 & 15.5 \\
Denemarken & 16.2 & 22.4 \\
Zwitserland & 10.6 & 12.2 \\
Zweden & -- & 24.1 \\
Japan & 3.7 & 5.7 \\
\hline
\end{tabular}

Bron: Unesco

Legenda: -- = niet aanwezig

\subsection{Aandeel van vrouwen in schoolverlaters van technische opleidingen}

Ten einde een indruk te krijgen van het aandeel van vrouwen met een technische opleiding dat beschikbaar komt voor de arbeidsmarkt, is het zinvol om naar het aantal schoolverlaters te kijken. Volgens de definitie van het CPB gaat het hierbij om mensen die beschikbaar komen voor 
de arbeidsmarkt. Tabel 30 geeft een beeld van het aandeel van vrouwen met een technische opleiding in het totale aantal schoolverlaters van technische opleidingen. Uit de tabel blijkt dat er sprake is van een stijging van het aandeel van vrouwelijke technisch opgeleiden dat beschikbaar komt voor de arbeidsmarkt, tenminste voor zover het opgeleiden op lager, middelbaar of hoger niveau betreft. Bij het WO is er sprake van een forse toename.

Tabel 30. Aandeel van vrouwelijke schoolverlaters met een technische opleiding (\%)

\begin{tabular}{|c|c|c|c|c|c|c|c|}
\hline \multicolumn{8}{|c|}{ Historische cijfers } \\
\hline & $\begin{array}{c}' 82 / ' 83 \\
\%\end{array}$ & $\begin{array}{l}' 85 / ' 86 \\
\%\end{array}$ & $\begin{array}{c}' 86 / ' 87 \\
\%\end{array}$ & $\begin{array}{c}' 87 / ' 88 \\
\%\end{array}$ & $\begin{array}{c}' 88 / ' 89 \\
\%\end{array}$ & $\begin{array}{c}' 89 / ' 90 \\
\%\end{array}$ & $\begin{array}{l}' 89 / 90 \\
N(=100 \%)\end{array}$ \\
\hline Lager Technisch & 2 & 3 & 3 & 4 & 4 & 5 & 900 \\
\hline Middelb. Technisch & 6 & 6 & 7 & 8 & 8 & 9 & 1100 \\
\hline Hoger Technisch & 2 & 4 & 6 & 5 & 5 & 6 & 500 \\
\hline WO-Technisch & 6 & 8 & 10 & 9 & 12 & 15 & 600 \\
\hline \multicolumn{8}{|c|}{ Prognoses } \\
\hline Opleiding & $\begin{array}{c}\text { '90/'91 } \\
\%\end{array}$ & $\begin{array}{c}' 91 / 92 \\
\%\end{array}$ & $\begin{array}{c}' 92 /{ }^{\prime} 93 \\
\%\end{array}$ & $\begin{array}{c}' 93 /{ }^{\prime} 94 \\
\%\end{array}$ & $\begin{array}{c}' 94 / ' 95 \\
\%\end{array}$ & $\begin{array}{c}\text { '2000/'01 } \\
\%\end{array}$ & $\begin{array}{l}' 2000 /{ }^{\prime} 01 \\
N(=100 \%)\end{array}$ \\
\hline Lager Technisch & 5 & 5 & 6 & 6 & 6 & 7 & 800 \\
\hline Middelb. Technisch & 10 & 10 & 11 & 11 & 12 & 13 & 1300 \\
\hline Hoger Technisch & 6 & 7 & 7 & 7 & 7 & 8 & 600 \\
\hline WO-Technisch & 16 & 18 & 19 & 19 & 19 & 19 & 1200 \\
\hline
\end{tabular}

Bron: ROA/CPB

\subsection{Aandeel van vrouwen in technische beroepen}

In vrijwel alle beroepen speelt techniek een rol. Een exacte afbakening van technische beroepen is daarom moeilijk te geven. Op grond van de nieuwe beroepsklassen-indeling van het ROA is een groot aantal beroepen geselecteerd die een overwegend technisch karakter hebben. Voor deze beroepsklassen wordt in tabel 31 het procentuele aandeel van vrouwen en een trendindicator met betrekking tot het percentage vrouwen weergegeven ${ }^{7}$. De beroepsklassen

7. De percentages zijn gemiddelden over 1979 en 1985 en gemiddelden over de jaren 19871990. De trendindicatoren zijn als volgt gedefinieerd:

Trend 79-85 = (Data' '85) / (Data '79)

Trend 87-90 $=($ Data'90 + Data'89) $/$ (Data'88 + Data'87) 
zijn in tabel 32 geaggregeerd tot drie clusters: bouw, metaal en elektrotechniek ${ }^{8}$.

Uit tabel 32 komt naar voren dat het aandeel van vrouwen in technische beroepen bijzonder gering is. Beroepsklassen in het cluster 'metaal' kennen een aandeel van $2 \%$ vrouwen over de jaren 1987-1990. Geconcludeerd kan worden dat er sprake is van een dalende trend bij kleine percentages.

De volgende beroepsklassen kennen een aandeel van vrouwen van meer dan $10 \%:^{9}$

- samenstellers electronische produkten: $\quad 33 \%$

- technische analisten, amanuences: $26 \%$

- drukkers, boekbinders e.d.:

- houtzagers, hout-, papiermakers e.d.:

$24 \%$

- technische en medische vertegenwoordigers:

$13 \%$

De volgende beroepsklassen kennen een duidelijk stijgende ontwikkeling in het aandeel van vrouwen over de laatste jaren (1987-1990):

- technische en medische vertegenwoordigers;

- houtzagers e.d.;

- architecten.

Geconcludeerd kan worden dat het aandeel van vrouwen in technische beroepen gering is. Bovendien is het aandeel van vrouwen in de meeste beroepsklassen de laatste jaren niet gestegen, maar gedaald. Wel is er een aantal beroepsklassen waar het aandeel van vrouwen meer dan $10 \%$ bedraagt en toeneemt, namelijk: houtzagers e.d., technische en medische vertegenwoordigers.

Het is niet mogelijk om de Nederlandse cijfers te vergelijken met cijfers van andere landen op het niveau van beroepsklassen. Op basis van de cijfers van de International Labour Organisation (1989) is het echter wel mogelijk om het percentage vrouwen in de categorie 'Professional, technical, and related workers' (ISCO-code $0 / 1$ ) te vergelijken (zie tabel 33). Deze cijfers moeten met de nodige omzichtigheid geïnterpreteerd worden, daar deze categorie niet alleen technici, maar ook medici, kunstenaars, juristen en leraren bevat. Deze bonte verzameling beroepen, die ook verzorgende beroepen omvat waar traditioneel veel vrouwen werkzaam zijn, kan slechts als een zeer ruwe benadering worden beschouwd van het aandeel van vrouwen in technische beroepen.

8. Eén beroepsklasse, namelijk 'drukkers, boekbinders, fotolaboranten', is niet ingedeeld in een cluster.

9. De cijfers tussen haakjes betreffen de nummers uit de beroepenclassificatie van het ROA. 
Tabel 31. Aandeel van vrouwen in technische beroepen, gemiddelde percentage en ontwikkelingstrend

Technische beroepen

gem. $\% \quad$ trend $\quad$ gem. $\%$ trend

\section{Beroepsklasse}

Bouw

3021 leidinggevenden bouw en industrie

3022 technische en medische vertegenwoordigers

3023 technische tekenaars

3024 technische analisten, amanuenses

3311 houtzagers, hout-, papier- en kartonmakers

3312 houtbewerkers, timmerlieden aardewerkindustrie

3911 metselaars, tegelzetters, straatmakers, stucadoors

3912 betonwerkers, dakdekkers, isoleerders, glaszetters

3913 huis-, scheeps- en constructieschilders

3914 loodgieters, sanitair-installateurs en -reparateurs

3921 bouwkundige technici, opzichters, werkvoorbereiders

3931 architecten, geodeten e.a. hogere bouwkundigen 3

3411 Drukkers, boekbinders, fotolaboranten

Metaal

3611 delfstoffenwerkers, metaalvervaardigers

3612 machinale metaalbewerkers

3613 lassers, constructiewerkers, edelmetaalsmeden

3614 machinebank- en plaatwerkers, gereedschapsen modelmakers

3615 onderhoudsmonteurs, fietsen- en instrumentenmakers

3621 auto-, motor- en bromfietsenmonteurs

3622 middelbare (scheeps)werktuigkundigen e.a. metaalkundigen

3631 hogere werktuigkundigen

\section{Elektrotechniek}

3711 samenstellers electrotechnische produkten, kwaliteitscontroleurs

3712 lijnwerkers, kabelmonteurs en -lassers

3721 electriciens, electro- en telecom(onderhouds)monteurs

3722 middelbare electrotechnici

3731 hogere electrotechnici
3031 bétaonderzoekers, technische vakspecialisten

3811 produktiepersoneel bouwmaterialen-, glas en
10

\subsection{4}

1.03

1.41

0.84

0.69

0.70

0.55

0.19

0.79

5

1

0

0

1

1

3

1

1

4

1

1

2

1

1

1

0

\section{7}

28

4

1

0

0
0.83

0.37

0.52

0.49

1.06

0.61

0.55

-

0.80

24

0.72

1.26

0.82

0.95

1.43

0

0

6

1.29

0.51

7

0.50

0.77

33

1.30

0.28

0

0.52

2

1.22

1.00
0.90

0.81
0.98

1.50

0.65
0.91

0.96

2.00

0.93

0.00

1.04

.52

Legenda: - = te kleine percenctages

Bron: ROA 
$-49-$

Tabel 32. Aandeel van vrouwen in technische beroepsklassen, gemiddelde percentage en ontwikkelingstrend

Cluster beroepsklassen

$1987-1990$

gem. \% trend

$\begin{array}{lll}\text { Bouw } & 6 & 0.81 \\ \text { Metaal } & 2 & 0.72 \\ \text { Elektrotechniek } & 7 & 0.50\end{array}$

Bron: ROA/CBS

Uit tabel 33 blijkt dat het aandeel van vrouwen in de beroepssector $0 / 1$ in Nederland lager ligt dan in de Verenigde Staten en Japan. Er is in Nederland wel sprake van een stabiele lichte stijging, terwijl het aandeel van vrouwen in de Verenigde Staten en Japan de laatste jaren constant dan wel dalend is.

Tabel 33. Aandeel van vrouwen in beroepssector 'professional, technical and related workers' (ISCO 0/1)

\begin{tabular}{lcccccc}
\hline & $\begin{array}{c}1981 \\
\%\end{array}$ & $\begin{array}{c}1983 \\
\%\end{array}$ & $\begin{array}{c}1985 \\
\%\end{array}$ & $\begin{array}{c}1987 \\
\%\end{array}$ & $\begin{array}{c}1988 \\
\%\end{array}$ & $\begin{array}{c}1989 \\
\%\end{array}$ \\
& & & & & & 42 \\
Nederland & 37 & 39 & 39 & 40 & 41 & 50 \\
Verenigde Staten & 45 & 48 & 49 & 50 & 49 & 42 \\
Japan & 46 & 47 & 46 & 43 & 43 & \\
\hline
\end{tabular}

Bron: ILO

\subsection{Conclusies}

Het percentage meisjes dat exacte vakken kiest is sinds 1980 gedaald bij het MAVO, redelijk constant gebleven bij het HAVO en gestegen bij het VWO. Biologie wordt steeds minder gekozen, wiskunde steeds meer. Jongens kiezen veel vaker dan meisjes exacte vakken. Voor verandering van het keuzegedrag is onderzoek naar de achtergronden van het keuzegedrag belangrijk. De sociale omgeving van meisjes (ouders/decanen/docenten) speelt een belangrijke rol bij het keuzeproces en het beleid zal daar meer aandacht aan moeten besteden.

De doorstroom van de middelbare school naar technische vervolgopleidingen op HBO-niveau is tamelijk constant voor meisjes. De doorstroompercentages zijn laag (in de buurt van de $8 \%$ ). Het aandeel van vrouwelijke eerstejaars in technische studierichtingen op WO-niveau vertoont 
een lichte stijging. In het jaar 2000 zal het percentage rond de $16 \%$ liggen. In vergelijking met andere landen scoort Nederland laag.

Het aandeel van vrouwen dat met een al dan niet afgeronde technische opleiding beschikbaar komt voor de arbeidsmarkt is laag. De percentages liggen beneden de $10 \%$, met uitzondering van het wetenschappelijk onderwijs. In een periode van 20 jaar (1980-2000) verdrievoudigd het aandeel van vrouwen.

Het aandeel van vrouwen in technische beroepen is bijzonder laag. Slechts een vijftal beroepsklassen kennen een aandeel van vrouwen van meer dan $10 \%$. Vergelijking met andere landen is moeilijk vanwege de verschillen in beroepsclassificaties. Desalniettemin kan geconstateerd worden dat Nederland laag scoort in vergelijking met andere landen bij de beroepsklasse, die onder meer technische beroepen omvat. 


\section{CONCLUSIES}

Op grond van de voorgaande hoofdstukken kunnen voor wat betreft de dit jaar verzamelde gegevens en de voortzetting van het METING-project de volgende conclusies worden getrokken.

De jaarlijkse actualisering van de kernindicatoren, waarvan de resultaten in hoofdstuk 2 zijn weergegeven, heeft dit jaar, met uitzondering van de prognoses (voor Nederland) van het aandeel van technisch geschoolden, geen noemenswaardige problemen opgeleverd. Dit jaar zijn twee kernindicatoren toegevoegd:

- De ontwikkeling van de afhankelijkheidsratio in 7 industrielanden op basis van prognoses van de Verenigde Naties (tabel 6). Aangezien het hierbij gaat om een lange termijn bevolkingsprognose (tot 2020 ) is een jaarlijkse actualisering niet nodig en kan worden volstaan met een actualisering wanneer een bijstelling van de VN-bevolkingsprognose daartoe aanleiding geeft.

- Het percentage werknemers met een primaire dan wel voortgezette leerovereenkomst per bedrijfssector (tabel 9 en 10) op basis van gegevens van het CBS en het CPB. Deze worden jaarlijks verstrekt, zodat een jaarlijkse actualisering van deze (voorgestelde) kernindicator plaats kan vinden.

Voor de in hoofdstuk 3 beschreven mailing van het netwerk (de verzameling van aanvullende internationaal vergelijkbare gegevens) moet worden opgemerkt dat deze dit jaar minder heeft opgeleverd aan directe 'treffers' dan vorig jaar. Uit de respons (zie bijlage I) blijkt echter wel steeds duidelijker welke instanties en personen tot de 'inner circle' behoren op het gebied van vergelijkbare statistieken op het door METING bestreken terrein. Uit de schriftelijke en telefonische reacties blijkt overigens dat er bij de nationale statistische bureaus een moeizame bereidheid bestaat tot internationale samenwerking (bij de verzameling van gegevens), aangezien dit een aanpassing van hun dataverzameling aan internationale standaarden met zich meebrengt. Dit is ook de reden waarom internationale organisaties als Eurostat, OECD en Unesco nog weinig gedetailleerde gegevens kunnen leveren die internationaal vergelijkbaar zijn.

Niettemin blijkt het individuele onderzoekers en instituten toch te lukken om zich te concentreren op de vergelijking van één aspect van technologie, arbeid of scholing om vervolgens na tijdrovende studie met enkele internationaal vergelijkbare cijfers te komen. De verzameling van dergelijke interessante publikaties door het jaar heen lijkt vruchtbaar te zijn, zodat voor METING 1992 als parool zou kunnen gelden: vinger aan de pols voor wat betreft ontwikkelingen in het internationale netwerk en door het jaar heen een open oog voor mogelijke internationale publikaties van derden.

Voor wat betreft de in hoofdstukken 4 en 5 opgenomen additionele thema-studies, zal met de 
opdrachtgever overlegd moeten worden of deze een vervolg zullen moeten krijgen. Als mogelijkheden voor landenstudies zouden na de Bondsrepubliek Duitsland, het Verenigd Koninkrijk en Zweden, genoemd kunnen worden: Japan, Denemarken en Frankrijk. In deze drie landen is zowel sprake van een hoge technologische ontwikkeling, als van een sterk gedecentraliseerde vorm van scholings- en werkgelegenheidsbeleid. $\mathrm{Na}$ het thema: 'de Nederlandse vrouw en techniek; scholing en arbeidsmarkt' zouden in 1992 enkele bedrijfstakken 'doorgelicht' kunnen worden voor wat betreft de in de bedrijfstak aanwezige capaciteit voor dataverzameling, onderzoek en beleidsontwikkeling op het gebied van (kosten en deelname) branche- en bedrijfsopleidingen. In een eerder door het ITS voor EZ/ATB verricht onderzoek werden hierin nogal grote lacunes geconstateerd (ITS, 1991).

Met ingang van 1992 zal het Maastricht Economic Research Institute on Innovation and Technology (MERIT) zorg dragen voor het onderhouden en verder uitbouwen van de METING databank omtrent de internationale economische positie van Nederland met betrekking tot de implementatie van technologie. De bijdrage van ROA aan METING gaat dan via MERIT verlopen. Deze bijdrage zal, evenals de afgelopen drie jaar, betrekking hebben op dié categorie van indicatoren binnen METING die gericht zijn op het technologisch potentieel van de beroepsbevolking. Dit betekent dat het ROA zorg blijft dragen voor een up date van de huidige kernindicatoren en blijft streven naar het verbreden c.q. verbeteren van de bestaande kernindicatoren op basis van een periodieke verkenning van relevante initiatieven bij internationale organisaties om te komen tot internationaal vergelijkbare indicatoren met betrekking tot onderwijs en arbeid. 


\section{LITERATUUR}

Altena, A.R. van, J. Plantenga, J.J. Schippers, J.J. Siegers (1990), Demografische ontwikkelingen en het functioneren van de arbeidsmarkt: een vergelijkende studie naar het overheidsbeleid in de Bondsrepubliek Duitsland, Frankrijk, Zweden en Nederland, OSA-W73, Den Haag.

Boot, P. (1989), Her- en bijscholing van werkenden, in: Tijdschrift voor politieke economie, $12 \mathrm{e}$ jaargang, nr. 3, januari 1990, p. 93-113.

Braams, M., M. Meesters (1991), Aanpassen en jezelf blijven; Schoolloopbanen en werkervaringen van meisjes met een technische opleiding, OSA W86, Den Haag.

Brouns, M., A. Schokker (1990), Arbeidsvraagstukken en sekse; Trendrapport, Stimuleringsgroep emancipatie-onderzoek, Den Haag.

Brouwer, H. (1990), Nederlandse mogelijkheden voor een Zweeds model?, in: Buitendam, A., e.a. (red), Het Zweedse model; geschikt voor import?, Van Gorcum, Assen/Maastricht.

Centraal Bureau voor de Statistiek (1991, 1990, 1989, 1988, 1987, 1983), Overgangen binnen het onderwijs en intrede in de maatschappij, onderwijsmatrix 1980-1989, Den Haag.

Centraal Bureau voor de Statistiek (), Statistiek van het beroepsonderwijs, 1964-1989.

Centraal Planbureau (1989), Tijdreeksen uit de onderwijsprognose 1989-1, Den Haag.

Dam, J.W. van, A. de Grip (1990), Technologie-indicatoren: bevolking, arbeid en scholing; rapportage 1990, ROA-R-1990/5, Maastricht.

Europa van Morgen, 21 (1991), nr. 26.

Grip, A. de (1987), Onderwijs en Arbeidsmarkt: Scholingsdiscrepanties, Amsterdam.

Grip, A. de, J.A.M. Heijke (1988), Arbeidsmarktindicatoren: een inventarisatie, ROA-W-1988/1, Maastricht.

Grip, A. de, W.J. Nusselder (1989), Technologie-indicatoren met betrekking tot scholing en arbeid, ROA-R-1989/4, Maastricht.

Hest, E., e.a. (1990), Vreemde talen in de markt, Ministerie van Onderwijs en Wetenschappen, Nijmegen.

IAB (1990), M. Tessaring e.a., Bildung und Beschäftigung im Wandel. Die Bildungsgesamtrechnung des IAB. Beiträge zur Arbeitsmarkt- und Berufsforschung 126, Nürnberg.

ILO (1989), Yearbook of Labour Statistics, International Labour Organisation, Geneva.

IRDAC (1991), Kwalificatietekorten in Europa, Industrial Research and Development Advisory Committee, Europese Commissie.

Koster, C. (1990), Behoeften aan vreemde talen, Lezing studiedag Taal en Bedrijf, VUTalencentrum, Amsterdam.

Kuyper, H., M.P.C. van der Werf (1991), De invloed van docenten op sekseverschillen met betrekking tot wiskunde, in: Tijdschrift voor Onderwijsresearch, 16 (1991), nr 1, pp. 3-18. 
Ministerie van Economische Zaken, Directie ATB (1988), Internationale beleidsvergelijking op het gebied van onderwijs en scholing: het Verenigd Koninkrijk.

Ministerie van Economische Zaken, Directie ATB (1990), Internationale beleidsvergelijking op het gebied van onderwijs en scholing: Bondsrepubliek Duitsland.

Ministerie van Economische Zaken, Directie ATB (1990), METING 2. Indicatoren voor de Technologische positiebepaling van Nederland.

Ministerie van Onderwijs en Wetenschappen (1990), Evaluatie voorlichtingscampagne Kies Exact, Zoetermeer.

Ministry of Labour (1985), The Swedish act on an employee's right to educational leave, Stockholm.

Ministry of Labour (1988), The labour market and labour market policy in Sweden - a discussion paper for the 1990s, Stockholm.

Ministry of Labour, B. Hultgren (1990), Guide : Vocational training system in Sweden, Stockholm.

Neubourg, C. de (1990), Jansen en Jonzon in de jaren tachtig: macro-economische en arbeidsmarktontwikkelingen in Zweden en Nederland, in: Buitendam, A., e.a.(red), Het Zweedse model; geschikt voor import?, Van Gorcum, Assen/Maastricht.

NIPO (1989), Schoolverlatersonderzoek, Amsterdam.

OECD (1991), Economic Outlook July 1991, Organisation for Economic Co-operation and Development, Paris.

Ours, van (1990), Arbeidsmobiliteit in internationaal perspectief', OSA-Voorstudie V-37, Den Haag.

Ours, van (1991), 'Een internationale vergelijking van arbeidsmobiliteit', in: Tijdschrift voor Arbeidsvraagstukken (7), 1991, nr.2, pp. 4-18.

Raadgevend Bureau Claessens (1990), Functie-eisen worden steeds strenger, Utrecht.

Swedish Ministry of Education and Cultural Affairs (1988), Development of education 19861988, National Report of Sweden, Stockholm.

Taakgroep Studentenraming (1990), HO-raming 1990; deel 1: WORSA, Zoetermeer.

UNESCO (1989), Statistical Yearbook, Paris.

Vries, B. de, B. Hövels (1991), Afgesproken! Onderzoek effectiviteit CAO-afspraken over scholing, ITS Nijmegen.

Wordelmann, P. (1991), Fremdsprachen in Ausbildung und Beruf, in: Gewerkschaftliche Bildungspolitik, nr. 2 '91.

Wouters, J. (1988), Werkloosheid: vatbaar voor beleid? een vergelijkend onderzoek naar werk loosheid in Nederland, Zweden en Zwitserland, Onderzoeksrapport Erasmus Universiteit Rotterdam, 8811/G, Rotterdam. 


\section{BIJLAGE I. INDELING BEDRIJFSSECTOREN}

\begin{tabular}{|c|c|c|}
\hline CPB-sector & CORO-sector & $\begin{array}{l}\text { opleidingsorganen door het } \\
\text { CBS onderscheiden }\end{array}$ \\
\hline $\begin{array}{l}\text { basismetaalindustrie, metaal- } \\
\text { produktie en grafische } \\
\text { industrie }\end{array}$ & metaal en electro & $\begin{array}{l}\text { metaaltechniek I t/m IV } \\
\text { motorvoertuigen, carrosserie, } \\
\text { installatietechniek } \\
\text { electrotechniek }\end{array}$ \\
\hline $\begin{array}{l}\text { hout- en bouwmaterialen- } \\
\text { industrie, } \\
\text { bouwnijverheid }\end{array}$ & bouw en hout & $\begin{array}{l}\text { bouwtechniek, houtbewer- } \\
\text { king, verfappl., wegenbouw, } \\
\text { meubel maken }\end{array}$ \\
\hline voedingsmiddelenindustrie & consumptief & consumptieve techniek \\
\hline $\begin{array}{l}\text { chemische- en } \\
\text { rubberindustrie }\end{array}$ & procestechniek & $\begin{array}{l}\text { proces-, meet- en } \\
\text { regeltechniek }\end{array}$ \\
\hline papier- en grafische industrie & grafisch & grafische opleidingen \\
\hline transportmiddelenindustrie & transport & $\begin{array}{l}\text { haven- en vervoerbedrijven } \\
\text { nautische opleidingen } \\
\text { personen- en goederen- } \\
\text { vervoer }\end{array}$ \\
\hline $\begin{array}{l}\text { textiel-/kleding-, leder- en } \\
\text { schoenindustrie }\end{array}$ & textiel en kleding & $\begin{array}{l}\text { textieltechniek, confectie, } \\
\text { sier- en graveertechniek }\end{array}$ \\
\hline
\end{tabular}




\section{BIJLAGE II. TOEGEZONDEN PUBLIKATIES PER LAND}

Naar land bezien, waren ook dit jaar de reakties vanuit Duitsland het meest talrijk en omvangrijk. Van de volgende (aangeschreven) organisaties werd een reaktie ontvangen (met tussen haakjes de relevante publikaties):

- Statistisches Bundesamt (Jahrbuch 1990; Bevölkerung und Erwerbstätigkeit 1989);

- Deutscher Gewerkschaftsbund (Berufliche Bildung 1990/1991; overnamen uit 'Bildungspolitik');

- Bundesinstitut für Berufsbildung (algemene informatie);

- Deutscher Institutsverlag (algemene informatie);

- Institut für Arbeitsmarkt- und Berufsforschung (Bildung und Beschäftigung in Wandel);

- Institut der Deutschen Wirtschaft (Hochschule-2000; Betriebliche Weiterbildung in der BRD);

- Der Bundesminister für Bildung und Wissenschaft (Berufsbildungsbericht 1990 en -1991; Studenten und Hochschulen 1975 bis 1990; Zahlenbarometer 1990/1991; Grund- und Strukturdaten 1989/1990 en -1990/1991);

Ook vanuit $Z$ weden werden er wederom enkele interessante publikaties toegezonden. Het aantal organisaties dat zich bezig houdt met het verzamelen en publiceren van onderwijsstatistieken is evenwel aanzienlijk minder dan in Duitsland. Het betreft:

- Statistiska Central Byran (Statistica Meddelanden-Education and Training of the Labour Force 1986 and 1987, Integrated Upper Secundary School 1989/1990, Higher Education 1989/1990; Labour Market Tendency Survey for some Training Categories in the Autumn 1990);

- Swedish National Board of Education (Educational and Training Characteristics, School Research Newsletters);

Vanuit de Verenigde Staten van Amerika werden van de volgende organisaties relevante publikaties ontvangen:

- US.Department of Education, National Center for Education Statistics (The condition of Education 1991, vol.1 -Elementary and Secondary Education- and vol.2 -Postsecundary Education-);

- US.Department of Labor, Bureau of Labor Statistics (How Workers get their Training, 1985; Occupational Outlook Quarterly, 1988; Employment and Earnings, 1991);

Organisaties uit het Verenigd Koninkrijk die publikaties verstuurden:

- The Employment Department Group (algemene informatie);

- Center for Labour Market Studies (algemene informatie); 
$-57-$

- Institute of Manpower Studies (Labour Markets and the Developments of People in the 1990's, Annual Report 1989/1990; The European Labour Market Review: the Key Indicators);

Uit Frankrijk werd informatie toegezonden door:

- Research Centre for Occupational and Training Analysis (Bilan Formation et Emploi, 1988; Statistique de la Formation Professionelle Continue, financee par les entreprises 1988/1989);

- BIPE-Conseil (Deformation des Structures de l'Emploi: Hausse des Qualifications et Promotions Interne); 


\section{BIJLAGE III. TOELICHTING ONDERWIJSTABELLEN}

In beginsel is het mogelijk om twee soorten cijfers te presenteren met betrekking tot de keuze van meisjes voor een technische vervolgopleiding: instroom- en uitstroompercentages. Instroompercentages betreffen het aantal meisjes dat voor een technische vervolgopleiding kiest als percentage van het aantal leerlingen in de 'ontvangende' technische vervolgopleiding. Uitstroompercentages betreffen het aantal meisjes dat een technische vervolgopleiding kiest als percentage van het aantal uitstromers uit de vooropleiding. Teneinde inzicht te krijgen in het keuzeproces bij leerlingen zijn uitstroompercentages relevanter. Indien de keuze voor een technische vervolgopleiding sexe-neutraal zou zijn, dan zouden de uitstroompercentages voor jongens en meisjes gelijk zijn. Een dergelijke relatie tussen de hypothese van sexe-neutraliteit en instroompercentages is er niet. Dit komt omdat het aantal meisjes dat had kunnen kiezen voor een technische vervolgopleiding in beginsel verschillend is van het aantal jongens dat had kunnen kiezen voor een technische vervolgopleiding.

De onderwijsmatrix van het CBS geeft inzicht in de uitstroom van verschillende vormen van onderwijs naar (technische) opleidingen. Aangezien hier de keuze voor technische opleidingen centraal staat, is ook het sexe-verschil in de keuze tussen beroeps- en algemene onderwijs uitgefilterd. Dit is gedaan door de uitstroom naar technische opleidingen te berekenen als percentage van de totale uitstroom naar een beroepsopleiding op hetzelfde niveau. De percentages worden voor jongens en meisjes per vooropleiding berekend. In de laatste kolom worden absolute aantallen voor 1989 gegeven. De volgende vooropleidingen worden onderscheiden:

- basis- en speciaal onderwijs (BAO/SO);

- MAVO 2 en hoger zonder diploma (MAVO2);

- MAVO 2 en hoger met diploma (MAVO2M);

- VWO en HAVO, leerjaren 2 en 3, (VWO/HAVO2);

- HAVO 4 en hoger zonder diploma (HAVO4);

- HAVO 4 en hoger met diploma (HAVO4M);

- VWO 4 en hoger zonder diploma (VWO4);

- VWO 4 en hoger met diploma (VWO4M);

(HAVO4X = HAVO4 + HAVO4M; VWO4X en MAVO2X zijn analoog gedefinieerd). 